\title{
Bacterial Membrane Vesicles in Pneumonia: From Mediators of Virulence to Innovative Vaccine Candidates
}

\author{
Felix Behrens ${ }^{1,2} \mathbb{D}^{D}$, Teresa C. Funk-Hilsdorf ${ }^{1}$, Wolfgang M. Kuebler $1,3,4,5, *,+\mathbb{D}$ and Szandor Simmons ${ }^{1,3,+}$ (D) \\ 1 Institute of Physiology, Charité-Universitätsmedizin Berlin, Charitéplatz 1, 10117 Berlin, Germany; \\ felix.behrens@charite.de (F.B.); teresa.funk-hilsdorf@charite.de (T.C.F.H.); szandor.simmons@charite.de (S.S.) \\ 2 Berlin Institute of Health (BIH), 10178 Berlin, Germany \\ DZHK (German Centre for Cardiovascular Research), Partner Site Berlin, 10117 Berlin, Germany \\ 4 The Keenan Research Centre for Biomedical Science at St. Michael's, Toronto, ON M5B 1X1, Canada \\ 5 Departments of Surgery and Physiology, University of Toronto, Toronto, ON M5S 1A8, Canada \\ * Correspondence: wolfgang.kuebler@charite.de; Tel.: +49-(0)30-450-528-501; Fax: +49-(0)30-450-528-920 \\ + These authors contributed equally to this work.
}

Citation: Behrens, F.; Funk-Hilsdorf, T.C.; Kuebler, W.M.; Simmons, S. Bacterial Membrane Vesicles in Pneumonia: From Mediators of Virulence to Innovative Vaccine Candidates. Int. J. Mol. Sci. 2021, 22, 3858. https://doi.org/10.3390/ ijms 22083858

Academic Editor: Andreas Spittler

Received: 14 March 2021

Accepted: 6 April 2021

Published: 8 April 2021

Publisher's Note: MDPI stays neutral with regard to jurisdictional claims in published maps and institutional affiliations.

Copyright: (c) 2021 by the authors. Licensee MDPI, Basel, Switzerland. This article is an open access article distributed under the terms and conditions of the Creative Commons Attribution (CC BY) license (https:/ / creativecommons.org/licenses/by/ $4.0 /)$.

\begin{abstract}
Pneumonia due to respiratory infection with most prominently bacteria, but also viruses, fungi, or parasites is the leading cause of death worldwide among all infectious disease in both adults and infants. The introduction of modern antibiotic treatment regimens and vaccine strategies has helped to lower the burden of bacterial pneumonia, yet due to the unavailability or refusal of vaccines and antimicrobials in parts of the global population, the rise of multidrug resistant pathogens, and high fatality rates even in patients treated with appropriate antibiotics pneumonia remains a global threat. As such, a better understanding of pathogen virulence on the one, and the development of innovative vaccine strategies on the other hand are once again in dire need in the perennial fight of men against microbes. Recent data show that the secretome of bacteria consists not only of soluble mediators of virulence but also to a significant proportion of extracellular vesicles-lipid bilayerdelimited particles that form integral mediators of intercellular communication. Extracellular vesicles are released from cells of all kinds of organisms, including both Gram-negative and Gram-positive bacteria in which case they are commonly termed outer membrane vesicles (OMVs) and membrane vesicles (MVs), respectively. (O)MVs can trigger inflammatory responses to specific pathogens including S. pneumonia, P. aeruginosa, and L. pneumophila and as such, mediate bacterial virulence in pneumonia by challenging the host respiratory epithelium and cellular and humoral immunity. In parallel, however, $(\mathrm{O}) \mathrm{MVs}$ have recently emerged as auspicious vaccine candidates due to their natural antigenicity and favorable biochemical properties. First studies highlight the efficacy of such vaccines in animal models exposed to (O)MVs from B. pertussis, S. pneumoniae, A. baumannii, and $K$. pneumoniae. An advanced and balanced recognition of both the detrimental effects of (O)MVs and their immunogenic potential could pave the way to novel treatment strategies in pneumonia and effective preventive approaches.
\end{abstract}

Keywords: pneumonia; lower respiratory tract infection; extracellular vesicles; outer membrane vesicles; membrane vesicles; vaccine

\section{Microbial Etiology of Lower Respiratory Tract Infections}

Pneumonia as the most common lower respiratory tract infection is the leading cause of infection-associated death worldwide, and the fourth most common cause of death globally [1,2]. Pneumonia is commonly classified into community-acquired pneumonia (CAP) and hospital-acquired pneumonia (HAP) [3], with HAP as the most frequent health care-associated infection [4]. Bacteria traditionally form the main causative pathogens of pneumonia [5]. While this is still the case for HAP, where Staphylococcus aureus and Pseudomonas aeruginosa dominate [6], vaccinations have changed the microbial etiology in CAP. In Europe Streptococcus pneumoniae (Pneumococcus) and Haemophilus influenzae are 
still the leading causes $[7,8]$, whereas in the United States respiratory viruses have become more frequently detected as possible causes of CAP as compared to bacterial pathogens [9], as summarized in Table 1. Epidemiological data suggest a U-shaped age distribution in pneumonia patients, with both younger children and elderly as main risk groups [10]. In addition, the risk of pulmonary infections is increased in patients with chronic respiratory diseases such as chronic obstructive pulmonary disease (COPD) and cystic fibrosis (CF) and in immunocompromised individuals [11-14].

Table 1. Microbial etiology of lower respiratory tract infections in different conditions [6-9,11,12,15-20].

\begin{tabular}{|c|c|c|c|}
\hline Disease & Common Pathogens & Proportion * & Less Common Pathogens \\
\hline CAP & $\begin{array}{c}\text { Streptococcus pneumoniae } \\
\text { Haemophilus influenzae } \\
\text { Influenza, other respiratory viruses }\end{array}$ & $\begin{array}{c}13-68 \% \\
1-45 \% \\
\text { up to } 71 \%\end{array}$ & $\begin{array}{l}\text { Mycoplasma pneumoniae } \\
\text { Legionella pneumophila } \\
\text { Staphylococcus aureus } \\
\text { Moraxella catarrhalis } \\
\text { Klebsiella pneumoniae } \\
\text { Mycobacterium tuberculosis }\end{array}$ \\
\hline HAP & $\begin{array}{c}\text { Staphylococcus aureus } \\
\text { Pseudomonas aeruginosa }\end{array}$ & $\begin{array}{l}15-36 \% \\
17-28 \%\end{array}$ & $\begin{array}{c}\text { Klebsiella pneumoniae } \\
\text { Acinetobacter baumannii } \\
\text { Enterobacter spp. } \\
\text { Escherichia coli } \\
\text { Stenotrophomonas maltophilia } \\
\text { Serratia spp. }\end{array}$ \\
\hline \multicolumn{4}{|c|}{ Predisposition } \\
\hline \multirow[t]{2}{*}{ COPD } & $\begin{array}{c}\text { Haemophilus influenzae } \\
\text { Streptococcus pneumoniae } \\
\text { Haemophilus parainfluenzae } \\
\text { Moraxella catarrhalis }\end{array}$ & $\begin{array}{c}14-39 \% \\
13-25 \% \\
13-25 \% \\
7-13 \%\end{array}$ & $\begin{array}{l}\text { Pseudomonas aeruginosa } \\
\text { Chlamydia pneumoniae } \\
\text { Mycoplasma pneumoniae }\end{array}$ \\
\hline & Influenza, other respiratory viruses & $20-40 \%$ & \\
\hline $\mathrm{CF}$ & $\begin{array}{l}\text { Staphylococcus aureus } \\
\text { Pseudomonas aeruginosa } \\
\text { Stenotrophomonas maltophilia } \\
\text { Haemophilus influenzae } \\
\text { Achromobacter spp. }\end{array}$ & $\begin{array}{c}45-80 \% \\
20-75 \% \\
10-18 \% \\
5-30 \% \\
3-30 \%\end{array}$ & $\begin{array}{c}\text { Burkholderia cenocepacia } \\
\text { Mycobacterium abscessus } \\
\text { Mycobacterium } \\
\text { avium-intracellulare }\end{array}$ \\
\hline
\end{tabular}

Advances in antimicrobial antibiotic therapy have drastically refined the treatment of pulmonary infections [5]. Additionally, the development of vaccines against common causes of lower respiratory tract infections, including S. pneumoniae, $H$. influenzae type $\mathrm{B}$, Bordetella pertussis, and seasonal influenza, has significantly reduced, albeit not eliminated, morbidity and mortality due to respective infections [21-23]. Concomitantly, new challenges have arisen for the treatment of patients with pneumonia. First, these include adaptive changes in microbial properties, like the rise of strains resistant to current vaccinations and established antibiotic regimes [24]. Second, a series of new zoonotic respiratory pathogens causing virgin soil epidemics in humans have arisen of late including swine and avian flu, and coronaviruses such as SARS, MERS, and SARS-CoV-2. Third, the pathophysiology of both acute and long-term complications of pneumonia including acute respiratory distress syndrome, sepsis, and cardiovascular complications, remain widely unknown and, therefore, at present difficult to treat or prevent [25-29].

Of late, extracellular membrane vesicles released from bacteria are increasingly recognized as molecular shuttles of nucleic acids, proteins, lipids, and carbohydrates involved in bacterial pathogenicity with the ability to target and (de)regulate host cells. Consequently, bacterial membrane vesicles start to receive noticeable attention for their potential role as detrimental mediators in bacterial infections [30]. In this review we summarize recent insights into the emerging role of bacterial membrane vesicles in the pathophysiology of 
pneumonia and its complications, and on their adoption as auspicious targets for future preventive and therapeutic approaches.

\section{2. (Outer) Membrane Vesicles-Biogenesis, Characteristics, and Analytical Methods}

Extracellular vesicles (EVs) are lipid bilayer-delimited particles that are spontaneously released from cells but, unlike cells, cannot replicate [31]. The release of EVs is a highly conserved mechanism in the vast majority of cells and organisms. As such, it is not limited to complex eukaryotic organisms, but equally present in bacteria, archaea, fungi, and parasites [32]. Both Gram-positive and Gram-negative bacteria produce EVs, which are referred to as membrane vesicles (MVs) and outer membrane vesicles (OMVs), respectively, based on their proposed mechanism or release [30]: while OMVs are thought to bleb from the outer membrane of Gram-negative bacteria and as such encapsulate periplasmatic content, MVs are considered to bud from the cytoplasmatic membrane of Gram-positive bacteria and accordingly, contain cytoplasmatic components [33,34]. In addition to OMVs, it has become clear that Gram-negative bacteria also release double and even triple membrane vesicles, which could be produced upon bacterial lysis or as a result of encapsulated bacteriophages respectively, even though these hypotheses need to be affirmed by appropriate testing and, thus, remain subjects of current research [34,35]. Yet, triggers and signaling pathways stimulating $(\mathrm{O}) \mathrm{MV}$ release, and the (selective) transfer of cargo into the vesicles and the molecular mechanisms regulating membrane-release remain incompletely understood. In contrast to fungi and mammalian cells, the mechanism of EV formation in intracellular multivesicular bodies, which release exosomes upon fusion with the cell membrane, does not seem to play a role in bacteria $[31,33,36]$.

(O)MVs are sized between 20 and $400 \mathrm{~nm}$ and contain a variety of cargo, including both cytosolic and surface proteins, nucleic acids, and virulence factors [30,32,34,37]. Notably, membrane composition of OMVs and MVs differs profoundly as a function of the releasing organism. For example, high levels of lipopolysaccharide (LPS) are omnipresent on OMVs, but non-existent on MVs [34]. OMVs were first discovered in the 1960s in Escherichia coli and considered as extracellular globules transporting the extracellular lipoglycopeptide consisting of LPS and polysaccharides [33,38]. In contrast, Gram-positive bacteria, and other organisms with thick cell walls, were long considered incapable of releasing EVs. This assumption led to a protracted discovery of MVs and a sustained knowledge gap regarding the mechanisms by which MVs break through the bacterial cell wall upon their release [33]. Although important aspects of $(\mathrm{O}) \mathrm{MV}$ genesis thus remain incompletely understood, recent studies have begun to shed light on the biological role of (O)MVs. Specifically, (O)MVs were found to play important roles in bacterial virulence, mediate horizontal gene transfer and other forms of cell-to-cell communication, and to confer immunomodulatory effects in host organisms [34].

Due to considerable heterogeneity in terminology, characterization, and analysis of EVs in initial studies-including those on (O)MVs—rigorous efforts have been undertaken of late with the aim of methodological standardization, and resulted in recent guidelines by the International Society for Extracellular Vesicles [39]. A broad variety of methods are presently used for both purification and isolation of EVs and in analytical approaches. Purification can be achieved by either (ultra-) centrifugation, size exclusion chromatography, affinity-based approaches, and other, less frequently applied methods, limiting direct comparability of purified EV samples in analytical and functional assays [40]. Key methods for the characterization of EVs/(O)MVs comprise (i) electron microscopy, which yields information on $\mathrm{EV} /(\mathrm{O}) \mathrm{MV}$ shape and size, yet is poorly suitable for high-throughput analysis [41]; (ii) light scattering-based methods, e.g., nanoparticle tracking analysis that allows for determination of $\mathrm{EV} /(\mathrm{O}) \mathrm{MV}$ size distribution and concentration yet without direct visualization [42]; and (iii) approaches to identify the molecular composition of EV/(O)MV. Among the latter, flow cytometry is most commonly used for the characterization of surface molecules [43], while classical biochemical and molecular biological methods and in particular innovative OMICS approaches can deliver in-depth analysis of important classes 
of EV/(O)MV cargo including proteins, nucleic acids, and lipids [39,44-46]. As none of these methods provides a comprehensive characterization of EVs/(O)MVs on its own, a panel of methods is ideally employed in order to provide robust data on $\mathrm{EVs}^{\prime} /(\mathrm{O}) \mathrm{MVs}^{\prime}$ physicochemical and biochemical properties.

\section{3. (O)MVs in Pneumonia-Release and Cargo}

Although the species of pathogens causing bacterial pneumonia are manifold, almost all strains release OMVs or MVs, respectively. In pneumonia, (O)MVs may be released by both common bacterial strains-like S. pneumoniae [47] - but also by less common pathogens such as $P$. aeruginosa, L. pneumophila, M. tuberculosis, A. baumannii, and $M$. catarrhalis [48-52]. These (O)MVs are increasingly recognized as essential parts of the secretome of lung pathogens that may carry a variety of cargo, which includes, but is not limited to proteins, nucleic acids, fatty acids, lipoproteins, and glycolipids [47-50]. Importantly, (O)MVs can transport relevant virulence factors such as pneumolysin in $S$. pneumoniae-secreted MVs, cystic fibrosis transductance regulator (CFTR) inhibitory factor (Cif) in P. aeruginosa-released OMVs, and macrophage infectivity potentiator (Mip) in L. pneumophila-derived OMVs $[47,49,53-55]$. While (O)MV cargo thus includes potentially harmful substances, limited data are available on the distribution of virulence factors as soluble mediators versus its encapsulated form in (O)MVs. Notably, the protein content of L. pneumophila-released OMVs and the composition of the respective soluble fraction of the extracellular fluid differ not only quantitatively, but also qualitatively. Specifically, the majority of virulence factors were identified in OMVs, including several proteins like Mip and flagellin uniquely present in OMVs but not detectable in the extracellular fluid [49]. However, further investigations are needed to assess the distribution of virulence factors for other pathogens, and to evaluate the relevance of this subcompartmentalization for the pathogenicity of the respective bacteria.

Interestingly, accumulating data indicate that host and environmental factors are able to modify both quantity of $(\mathrm{O}) \mathrm{MV}$ release and quality of (O)MV cargo. For example, $P$. aeruginosa isolates from CF patients release OMVs bearing higher concentrations of the $P$. aeruginosa aminopeptidase ( $\mathrm{PaAP}$ ) as compared to an environmental isolate, which was demonstrated to favor OMV binding to epithelial cells, even though the underlying mechanisms of enhanced OMV-binding remain elusive [56,57]. As such, the specific microenvironment of a disorder may directly foster the development of highly virulent pathogens that release potent OMVs in the alveolar compartment. Similarly, antibiotic treatment against the colonialization with pathogens may trigger OMV release. For example, $A$. baumannii produces more than twofold higher concentrations of $\beta$-lactamase-, protease-, and other protein-loaded OMVs when treated with imipenem [58]. Bacterial $\beta$-lactamases are able to deactivate a variety of $\beta$-lactam antibiotics (e.g., imipenem), pointing towards adaptive mechanisms that bacteria can upregulate in response to extrinsic stress [58]. In line with this notion, $\beta$-lactamases in OMVs from $M$. catarrhalis were found to reduce antibiotic effects of amoxicillin on S. pneumoniae in vitro [52]. These observations highlight the potential of $(\mathrm{O}) \mathrm{MVs}$ to modulate pharmacological substances; a point of consideration that should be taken into account in the future design of treatment regimens against bacterial lung infections and in the growing problem of emerging antibiotic resistance.

Several pathogenic bacterial species causing atypical pneumonia also evolved ingenious strategies to traverse host epithelial barriers by hijacking phagocytic host cells, i.e., alveolar macrophages. In this "Trojan Horse" mechanism M. tuberculosis is phagocytosed and transported across the gas-blood barrier using diapedesis of the infected macrophage [59]. Moreover, mycobacteria, e.g., M. tuberculosis and most other pathogenic strains of this species, and legionella, e.g., L. pneumophilia, exploit macrophages as their replicative niche for most of the lifecycle; a competence that constitutes a defining feature of the species' pathogenicity $[60,61]$. A prerequisite for this very efficient strategy is the ability of these intracellular pathogens to release molecules that modulate the host immune response. Here, $(\mathrm{O}) \mathrm{MV}$ s emerge as mediators of pathogenicity that allow bacteria to outwit, 
exploit, or bypass host defense mechanisms. Specifically, EVs released from mycobacteriainfected macrophages bear bacterial cargo, and in turn activate proinflammatory responses and modulate innate immune mechanisms [62-67]. Of note, recent data show that virulent mediators of $M$. tuberculosis comprising bacterial lipoglycans and lipoproteins are released from macrophages in bacterial MVs as opposed to "regular" macrophage-derived EVs [68]. So far, insight into the intracellular biogenesis and release of $(\mathrm{O}) \mathrm{MV}$ in host cells is limited; yet it seems plausible that the intracellular milieu of the host cell could have a major influence on $(\mathrm{O}) \mathrm{MV}$ characteristics and quantity. Taken together, environmental circumstances and the intra- and extracellular host milieu have a considerable influence on bacterial (O)MV cargo and release. Therefore, these important confounders should be recognized in a comparison of the modulating effects of $(\mathrm{O}) \mathrm{MVs}$ of diverse bacterial origin on the infected tissue.

\section{The Interaction of $(\mathrm{O}) \mathrm{MVs}$ with The Respiratory Epithelium-A First Step in Immunoactivation}

Upon colonialization of the mucosal surfaces of bronchi and bronchioles, and/or the alveolar compartment with bacterial pathogens the epithelial barrier forms the primary antimicrobial barrier but concomitantly also the first surface of interaction with (O)MVs. (O)MVs bind to the bronchial epithelium, as shown for P. aeruginosa OMVs [69], and alveolar epithelial cells, as demonstrated for A. baumannii OMVs and S. pneumoniae MVs [51,70]. Notably, for EVs an important role of CD44 in the EV binding process has been well documented [71,72]. As CD44 is the hyaluronic receptor, and hyaluronan forms an important constituent of both the alveolar epithelial glycocalyx and airway mucus, a similar "attachment chemistry" may also exist in (O)MVs but remains to be identified [73,74]. Interestingly, the $(\mathrm{O}) \mathrm{MV}$-epithelial interaction is not limited to membrane binding, since $P$. aeruginosa OMVs are able to fuse with bronchial epithelial cells [75], and (O)MVs from several bacteria such as A. baumannii and S. pneumoniae can be incorporated by alveolar epithelial cells $[51,70,76]$. In this context it is worth to speculate whether $(\mathrm{O}) \mathrm{MVs}$ could actually be transcytosed through the alveolar barrier allowing for infectious dissemination throughout the body. While such mechanisms were not described in the lung yet, it was already shown in the gut that $(\mathrm{O}) \mathrm{MVs}$ are indeed able to cross epithelial barriers and enter the vascular system [77,78]. On the functional level, OMVs from a variety of lung pathogens including P. aeruginosa, L. pneumophila, A. baumannii, K. pneumoniae, M. catarrhalis, and S. maltophilia can induce the release of proinflammatory mediators from the epithelium. The generated cytokines include but are not limited to interleukin (IL)-1 $\beta$, IL-6, IL-7, IL-8, IL-13, tumor necrosis factor $\alpha$ (TNF- $\alpha$ ), interferon- $\gamma$ (IFN $\gamma$ ), granulocyte colony-stimulating factor (G-CSF), and monocyte chemoattractant protein 1 (MCP-1) [49,56,79-82]. While these findings document a considerable range of cytokines released from the epithelium upon the OMV challenge, the underlying mechanisms how OMVs trigger cytokine release from epithelial cells remain largely unknown. That notwithstanding, the resulting epithelial cytokine responses do have a major impact on the immune response to pathogens and, importantly, also on alveolar barrier function. P. aeruginosa OMV challenge was shown to be sufficient to induce alveolar barrier failure, as indicated by cellular infiltration and protein leak into the alveolar space [83]. Other studies also revealed cytotoxic effects of OMVs from L. pneumophila, A. baumannii, and S. maltophilia on the alveolar epithelium, as indicated by epithelial delamination, mitochondrial fragmentation, and the development of a necrotic phenotype $[51,82,84]$. In the case of $A$. baumannii OMVs may carry the outer membrane protein $\mathrm{A}\left(\mathrm{Omp}_{\mathrm{Ab}}\right)$, which activates the host GTPase dynamin-related protein 1 (DRP1) in alveolar epithelial cells in vitro [51]. DRP1 activation leads to mitochondrial fragmentation, production of reactive oxygen species, and, eventually, epithelial cell death. Both bacterial/OMV-transported Omp $\mathrm{Ab}_{\mathrm{b}}$ and its activation of DRP1 were shown to play important roles in the virulence of $A$. baumannii as bacterial loss of Omp $\mathrm{Ab}_{\mathrm{Ab}}$ reduced bacterial growth and systemic spread in vivo, and DRP1 RNA interference prevented OMV-induced epithelial damage [51]. Whereas this recently identified mechanism of OMV-induced mitochondrial dysfunction sparks efforts to understand OMV-mediated epithelial cell injury, 
further studies are needed to understand whether this pathway may constitute a common pathogenic mechanism shared by other pulmonary pathogens in the induction of alveolar barrier disruption as hallmark of respiratory failure.

Pulmonary epithelial dysfunction plays a particularly important role in CF. Affected patients suffer from genetically determined dysfunction of the anion channel cystic fibrosis transmembrane conductance regulator (CFTR), which causes decreased chloride and bicarbonate secretion from the epithelium, resulting in airway surface dehydration and impaired mucociliary clearance [16,85]. The resulting highly viscous mucoid plaques within the airways form a fertile breeding ground for infections, which are responsible for a high proportion of $\mathrm{CF}$ morbidity and are commonly caused by methicillin-resistant S. aureus, and opportunistic respiratory pathogens such as P. aeruginosa $[17,86]$. CFTR mutations are classified into six groups, with class I to III comprising no residual CFTR function, whereas class IV to VI maintain residual CFTR function, which is highly predictive for disease outcome [16]. Accordingly, inhibitory effects on residual CFTR should be avoided as they further worsen the clinical outcome in CF patients. P. aeruginosa-being one of the main infectious agents in $\mathrm{CF}$-releases OMVs that bind to airway epithelial cells and interact specifically with cholesterol-rich lipid rafts and the neural Wiskott-Aldrich syndrome protein (N-WASP), which mediates the interaction of extracellular ligands with the actin cytoskeleton $[69,75]$. P. aeruginosa-secreted OMVs transport various virulence factors, i.e., $\beta$-lactamases, hemolytic phospholipase $C$, and, as aforementioned, Cif [75]. As such, OMVs can inhibit epithelial CFTR in a Cif-dependent manner [75]. Specifically, Cif inhibits the deubiquinating enzyme ubiquitin specific peptidase 10 (USP10), thereby reducing the USP10-mediated deubiquination of CFTR and promoting CFTR trafficking to and degradation in lysosomes [87]. As a result, Cif inhibits physiological cellular functions that depend on intact CFTR function [88]. Reduced USP10 activity in response to Cif also increases degradation of the transporter associated with antigen processing 1 (TAP1), lowering antigen presentation on major histocompatibility complex-I (MHC-I) molecules on epithelial cells through decreased peptide antigen translocation into the endoplasmic reticulum, which subsequently reduces the adaptive immune response [89]. Hence, $P$. aeruginosa OMVs may initiate a vicious cycle of opportunistic infection resulting in a worsening of mucociliary clearance and restriction of a competent immune response, which further increase the susceptibility to bacterial and other infections. An initial approach to overcome this pathophysiology by reducing membrane cholesterol by cyclodextrins (hydroxy-propyl- $\beta$-cyclodextrin and methyl- $\beta$-cyclodextrin) proved efficient in limiting the binding of $P$. aeruginosa-released OMVs to epithelial lipid rafts and thus restoring $\mathrm{Cl}^{-}$secretion in airway epithelial cells in vitro [69]. Future research will have to probe whether strategies to reduce membrane cholesterol levels in vivo by, e.g., statins or dietary restrictions may similarly reduce OMV-binding to epithelial target cells and thus overall bacterial pathogenicity.

\section{The Effect of (O)MVs on Innate Immunity-Novel Regulators of Immune Response}

Alongside the interaction of $(\mathrm{O}) \mathrm{MVs}$ with the lung epithelium their role in facilitating a proinflammatory response that activates innate immune cells has received considerable attention (Figure 1). Binding and uptake of (O)MVs was also shown for cells of the innate immune system. In ex vivo experiments, L. pneumophila OMVs primarily bind to macrophages within human tissue sections [84] and are subsequently internalized in a predominantly phagocytosis-independent manner [90]. Similarly, MVs from S. pneumoniae can be incorporated into both macrophages and dendritic cells (DCs), with uptake into DCs happening noticeably faster and again at least partially independent of phagocytosis $[70,76]$. (O)MVs induce inflammatory activation of innate immune cells, as reflected by increased release of cytokines including IL-1 $\beta$, IL-6, IL-8, TNF- $\alpha$, and CXCL2 from macrophages exposed to (O)MVs from P. aeruginosa, L. pneumophila, H. influenzae, S. pneumonia, A. baumannii, or M. catarrhalis [90-95]. In DCs, MVs from S. pneumoniae were likewise shown to increase the production of IL-6, IL-8, IL-10, and TNF- $\alpha$, even though associated functional 
consequences on DC activity with respect to phagocytosis, migration to lymph nodes, and expression of costimulatory molecules remain unclear [70,76]. Analysis of underlying signaling mechanisms revealed that the stimulation of innate immune cells by (O)MVs is mediated via unique activation pathways. For example, $P$. aeruginosa-secreted OMVs trigger NLRP3 inflammasome activation, resulting in macrophage activation and IL-1 $\beta$ production and release $[91,92]$. This macrophage activation seems to be essentially dependent on toll-like receptor (TLRs)-signaling that leads to non-canonical inflammasome-dependent caspase-11 activation, which neglects the canonical AIM2 and NLRC4 inflammasome challenge [92]. Murine caspase- 11 has two human homologues, caspase- 4 and caspase- 5 , of which caspase- 5 has been identified to be specifically activated by the OMV interaction with macrophages, whereas cytoplasmic LPS results in caspase-4 activation [92]. Since LPS is expected to be present on all OMVs one could speculate that LPS also accounts for TLRdependent caspase- 5 activation upon challenge with P. aeruginosa-derived OMVs. Indeed, evidence was provided that inhibition of LPS on P. aeruginosa OMVs markedly reduced macrophage activation, as indicated by decreased IL-6, TNF- $\alpha$ and CXCL2 release [93]. Nonetheless, further studies will have to consolidate whether macrophage activation by OMVs via the non-canonical inflammasome pathway is in fact LPS-dependent, and whether this potential mechanism can be translated to other pathogens.

Similar to P. aeruginosa, OMVs released from L. pneumophila and A. baumannii also activate macrophages in a TLR-dependent manner $[95,96]$. A proinflammatory response in uninfected macrophages can be initiated in a TLR- and myeloid differentiation factor (MyD88)dependent way. In the case of L. pneumophila TLR2 is required for bystander macrophage polarization by OMVs carrying pathogen-associated molecular patterns (PAMPs) [96], which goes in line with the observation that OMVs quantitatively enhance proinflammatory cytokine secretion from initially classically activated macrophages [97]. While this activation results at first in a suppressed bacterial expansion, OMVs subsequently promote bacterial growth, as demonstrated for intracellular L. pneumophila replication by miRNA146a-dependent Interleukin-1 receptor-associated kinase 1 (IRAK1) degradation within macrophages later during infection [97]. Additionally, L. pneumophila-secreted OMVs can attenuate phagosome-lysosome fusion in macrophages, thus further contributing to the elevated bacterial load [98].

In case of A. baumannii infection the induction of IL-6 secretion from macrophages depends on TLR4 signaling [95]. TLR-dependency of the innate immune response is also evident in vivo, as macrophage and neutrophil infiltration into the alveolar space in response to OMV exposure was reduced in TLR4-deficient mice [95]. Moreover, $A$. baumannii-derived OMVs also cause mitochondrial damage via an $\mathrm{OmpA}_{\mathrm{Ab}}$-dependent pathway in alveolar macrophages in vivo, as mechanistically described above concerning pulmonary epithelial cells [51]. Hence, OMVs not only induce an innate immune response via various mechanisms but also promote bacterial immune evasion. Future research will need to probe to which extent either of these pathways contributes to the pulmonary congestion and neutrophil infiltration observed upon stimulus with $A$. baumannii-derived OMV [95].

While the aforementioned studies mainly focused on the cellular aspect of innate immunity and resulting changes in cytokine release, limited data are available with regard to the direct interaction of $(\mathrm{O}) \mathrm{MVs}$ with humoral mediators. S. pneumoniae-released MVs were shown to inhibit the release of neutrophil extracellular traps (NETs) by transferring the bacterial DNAse TatD to neutrophils [55]. NETs trap extracellular bacteria and fungi in complexes of nuclear chromatin and bactericidal proteins to reduce their dissemination and limit the spread of infection [99]. Consequently, depletion of TatD in S. pneumoniae decreased bacterial replication in a murine pneumonia model in vivo, and as such protected against fatal outcome [55]. Another study demonstrated that $S$. pneumoniae-secreted MVs bind to the complement proteins $\mathrm{C} 3, \mathrm{C} 5 \mathrm{~b}-9$ and factor $\mathrm{H}$, and reduce complementdependent opsonophagocytic killing of S. pneumoniae by macrophages in an adhesion and phagocytosis assay in vitro [70]. C3 and C5b-9 have key roles in the opsonization of 
pathogens $[100,101]$, whereas factor $H$ is considered as an inhibitor of the complement system, maintaining balance between pathogen defense and inhibiting complement activation by host factors [102]. Therefore, the exact mechanisms by which the imbalance in the complement cascade resulting from parallel binding of MVs to both stimulating and suppressing components diminishes bacterial killing remain to be elucidated.

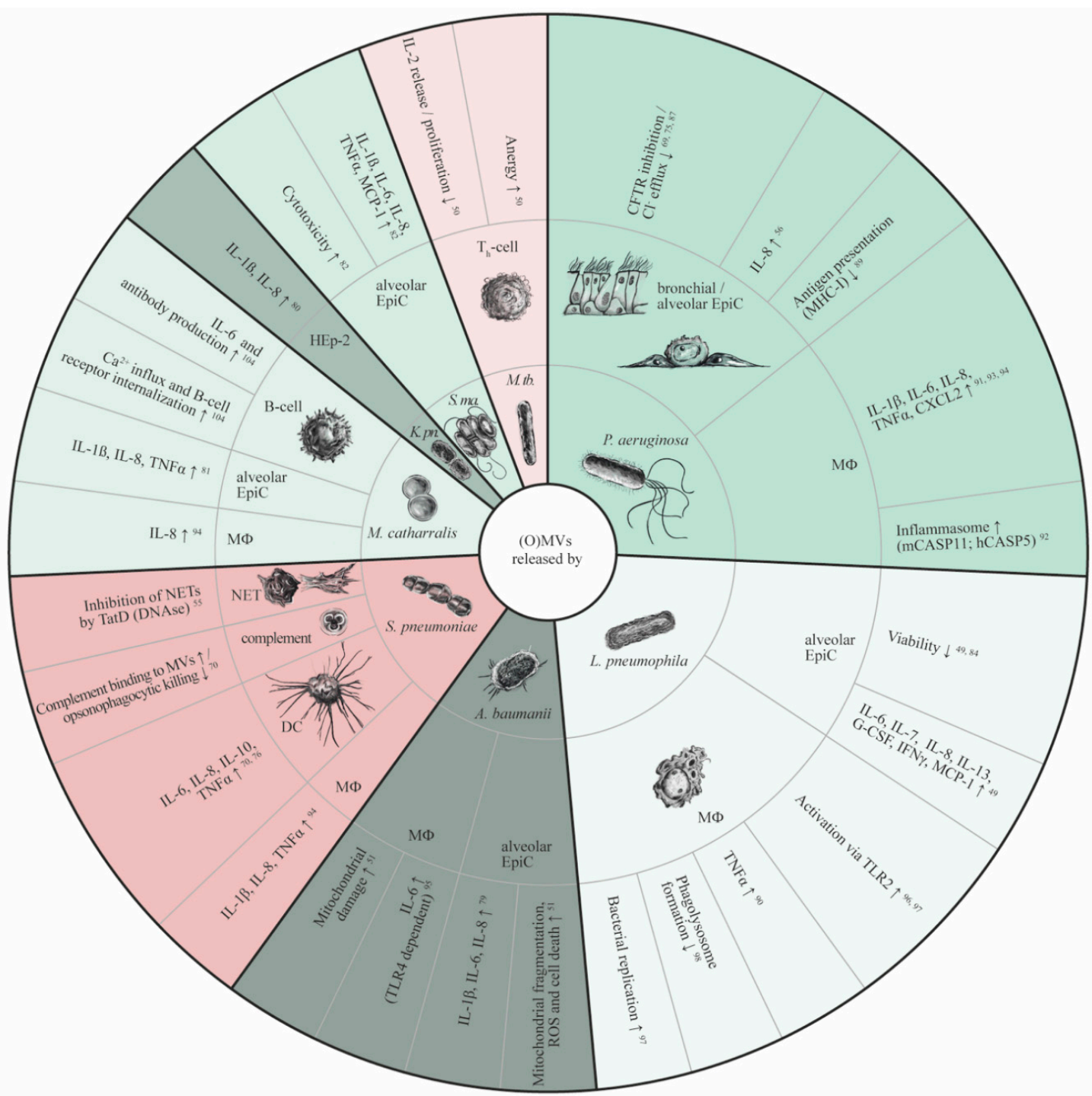

Figure 1. Functional properties of $(\mathrm{O}) \mathrm{MVs}$ in pneumonia. Inner ring: (O)MV-releasing bacterial species; middle ring: $(\mathrm{O}) \mathrm{MV}$ target cells; outer ring: $(\mathrm{O}) \mathrm{MV}$-mediated effects on target cells. Red areas: Gram-positive bacteria; green areas: Gram-negative bacteria. CFTR, cystic fibrosis transductance regulator; DC, dendritic cell; EpiC, epithelial cell; G-CSF, granulocyte colony-stimulating factor; hCASP5, human caspase-5; mCASP11, murine caspase-11; IFN $\gamma$, interferon- $\gamma$; IL, interleukin; K. pn., Klebsiella pneumoniae; M. tb, Mycobacterium tuberculosis; MCP-1, monocyte chemoattractant protein-1; MHC-I, major histocompatibility complex-I; M $\Phi$, macrophage; NET, neutrophil extracellular trap; S. ma., Stenotrophomonas maltophilia; TLR, toll-like receptor; TNF $\alpha$, tumor necrosis factor $\alpha$.

An increasing body of work sheds light on important immunomodulatory interactions of $(\mathrm{O}) \mathrm{MVs}$ with cellular and humoral components of the innate immune system in pneumonia. (O)MVs released by a variety of pulmonary pathogen species are capable of inducing potent (pro)inflammatory responses and in parallel facilitate a broad range of immune evasion mechanisms of the host pathogen, which can aggravate the course of disease. (O)MVs alone are competent to evoke pathologies comparable to bacterial pneumonia, as exemplarily shown for K. pneumoniae-derived OMVs [80]. Yet, the molecular 
mechanisms by which $(\mathrm{O}) \mathrm{MVs}$ mediate evasion of pathogens from the complement system and NETs remain unclear so far and form an important topic for antimicrobial research.

\section{6. (O)MVs and Adaptive Immunity}

Knowledge on the effect of (O)MVs on the adaptive immune system is limited. However, the altered cytokine response of pulmonary epithelial cells and tissue-resident and immigrating innate immune cells can be expected to trigger activation of both B- and T-cells, their maturation in lung draining lymph nodes and at the site of infection, and eventually the formation of tertiary lymphoid organs in the lung. However, the evidence for lymphocyte infiltration and expansion upon stimulation with (O)MV remains limited for pneumonia. The first indication of a putative modulation of adaptive immunity by (O)MVs was provided by the observation that intracellular MVs produced by M. tuberculosis in infected macrophages shuttle mycobacterial lipoglycans-known as virulence factors-to $\mathrm{CD}^{+}{ }^{+} \mathrm{T}$-cells [50]. As a result, MVs decreased IL-2 secretion and, thereby, limited autocrine-activation of T-helper cell expansion and maturation [50]. These initial signs of T-cell anergy are highlighted by mycobacterial MVs inducing expression of the gene related to anergy in lymphocytes (GRAIL) and consequently reduced proliferation upon restimulation [50].

M. catarrhalis is a respiratory-tract commensal organism, which not only causes infections of the lower but also the upper respiratory tract [103]. As commensal organism M. catarrhalis often resides in the tonsils that are part of the pharyngeal lymphoid tissue. In fact, tonsils are secondary lymphoid organs that are constantly exposed to airborne antigens and are predominantly populated by B-cells, which accordingly play an important role in the regulation of $M$. catarrhalis infection [104]. Like other secondary lymphoid tissues, tonsils are sites of increased expansion of B-cell diversity and memory providing an environment for plasma cell differentiation and effector B-cell development, including IL-10 and IL-35 secreting regulatory B-cells $\left(\mathrm{B}_{\text {reg }}\right)$, which play significant roles in the control of the tonsillar commensal bacterial flora $[105,106]$. OMVs released by M. catarrhalis bind to immunoglobulin $\mathrm{D}(\mathrm{IgD}) \mathrm{B}$-cell receptors depending on moraxella $\mathrm{IgD}$ binding protein (MID), induce $\mathrm{Ca}^{2+}$ influx, and, eventually, B-cell receptor internalization [104]. On top of that, OMVs activate an inflammatory response in B-cells as indicated by IL-6 and IL-10 release and antibody production, which is attenuated in absence of MID on OMVs [104]. However, the functional consequences of this response remain unclear. While Vidakovics et al. hypothesize that this pathway leads to a T-cell-independent B-cell response with impaired bacterial killing, evidence for increased bacterial survival is outstanding and remains to be tested in further studies [104].

\section{7. (O)MVs as Novel Vaccine Candidates against Pulmonary Infection}

Several bacterial pathogens that induce infections in the lung are at present still poorly treatable and have detrimental long-term effects that could be prevented by effective vaccination. These include, e.g., B. pertussis, S. pneumoniae, A. baumannii, and K. pneumoniae, the two latter causing mainly nosocomial infections $[107,108]$, whereas B. pertussis and $S$. pneumoniae are commonly community-acquired $[109,110]$. (O)MVs have been considered as auspicious vaccine candidates since they elicit potent immune responses, could be an easy-to-store off-the-shelf product, and distribute well in the organism after parenteral application [111,112]. Together, these beneficial properties initiated the development of a first clinically licensed OMV vaccine, which acts against Neisseria meningitidis serogroup B, representing the first effective vaccine against this meningococcal disease causing pathogen [113]. Nonetheless, like other vaccine candidates, $(\mathrm{O}) \mathrm{MV}$ vaccines require careful consideration regarding the balance of immunizing effects and potential side effects, including a strong inflammatory response or even proinfectious effects in case of bacterial superinfection.

Due to the fact that $B$. pertussis has developed high levels of resistance against the acellular vaccine that is currently used in large parts of the world [114] substantial efforts have been made to develop $B$. pertussis OMVs as a vaccine candidate against whooping cough. 
Several studies show that application of $B$. pertussis OMVs can prevent subsequent fatal infections with B. pertussis and reduce bacterial load in mice [115-118], while also efficiently preventing infection by serotypes commonly unaffected by conventional acellular vaccination $[119,120]$. Mechanistically, OMVs induced a combined T- and B-cell response (Table 2), as demonstrated by a profound $\mathrm{T}_{\mathrm{h} 1}, \mathrm{~T}_{\mathrm{h} 2}$, and $\mathrm{T}_{\mathrm{h} 17}$ response, and production of neutralizing antibodies and colonization of lung resident B- and T-cells [115,116,118-122]. Importantly, effective immunization by OMVs seems to depend on the presence of virulence proteins exposed on the vesicular surface, including pertussis toxin [123,124]. Accordingly, thorough testing for the safety of vaccine candidates is mandatory to exclude that OMV-associated toxins could confer harmful effects. Approaches to reduce OMV toxicity by expressing the lipid A deacylase PagL in OMVs released by B. pertussis yielded promising results, in that vaccine toxicity was reduced yet immunogenicity preserved [125]. Besides considerations for safety, immunogenicity, and protective efficacy, the ideal administration route and/or method for OMV vaccines remains to be determined. Indeed, intranasal inhalation as compared to subcutaneous or intraperitoneal injection of OMVs elicits qualitatively distinct immune responses, resulting in incomplete protection following subcutaneous injection as compared to intranasal application $[115,116]$.

Table 2. Immunogenic properties of (O)MV vaccine candidates against bacterial pathogens causing lower respiratory tract infections.

\begin{tabular}{|c|c|c|c|c|}
\hline Pathogen & Immunogenic (O)MVs & Cellular and Humoral Immunity & Vaccine Efficacy & Side Effects \\
\hline $\begin{array}{c}\text { B. pertussis } \\
\text { (a) }\end{array}$ & $\begin{array}{c}\text { native [115-125] } \\
-\overline{\text { engineered (decreased }} \\
\quad \text { endotoxicity) [125] }\end{array}$ & $\begin{array}{c}\mathrm{T}_{\mathrm{h} 2}, \mathrm{~T}_{\mathrm{h} 17}, \mathrm{~T}_{\mathrm{RM}}, \mathrm{B}_{\mathrm{RM}} \text {, plasma cells } \\
\text { not reported }\end{array}$ & $\begin{array}{l}\text { reduced bacterial load, } \\
\text { protection against } \\
\text { fatal outcome } \\
\text { similar reduction in } \\
\text { bacterial load }\end{array}$ & $\begin{array}{c}\text { weight loss } \\
\text { not reported }\end{array}$ \\
\hline S. pneumoniae & $\begin{array}{c}\text { native [47] } \\
\text { engineered (S. } \\
\text { typhimurium/E. coli } \\
\text { OMVs) [126-128] }\end{array}$ & 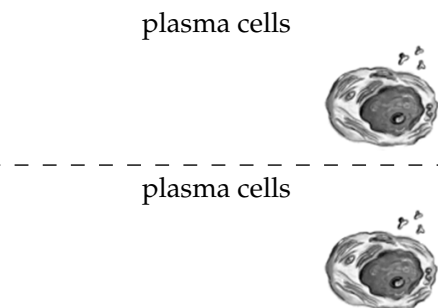 & $\begin{array}{l}\text { protection against } \\
\text { fatal outcome } \\
\\
\text { reduced bacterial load, } \\
\text { protection against } \\
\text { fatal outcome }\end{array}$ & $\begin{array}{c}\text { not reported } \\
\\
\text { weight loss (S. } \\
\text { typhimurium } \mathrm{OMVs})\end{array}$ \\
\hline 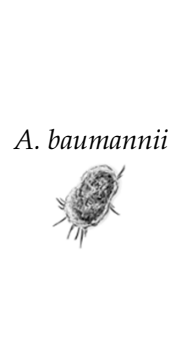 & $\begin{array}{c}\text { native [129-134] } \\
\\
\text { engineered } \\
\text { (LPS-depletion, E. coli } \\
\text { OMVs) [131,135,136] }\end{array}$ & $\mathrm{T}_{\mathrm{h} 2}$, DCs, plasma cells & $\begin{array}{l}\text { protection against } \\
\text { fatal outcome } \\
\\
\text { reduced inflammation } \\
\text { and bacterial load, } \\
\text { protection against } \\
\text { fatal outcome }\end{array}$ & $\begin{array}{l}\text { not reported } \\
\text { LPS-depletion: partly } \\
\text { ineffective protection }\end{array}$ \\
\hline $\begin{array}{c}\text { K. pneumoniae } \\
\end{array}$ & $\begin{array}{c}\text { native [137] } \\
\text { engineered } \\
\text { (nanoparticle-bound } \\
\text { OMVs) [138] }\end{array}$ & $\mathrm{T}_{\mathrm{h} 1}$, plasma cells & $\begin{array}{l}\text { dose-dependent } \\
\text { protection against } \\
\text { fatal outcome } \\
---------- \\
\\
\text { complete protection } \\
\text { against fatal outcome }\end{array}$ & $\begin{array}{l}\text { not reported } \\
\text { not reported }\end{array}$ \\
\hline
\end{tabular}

All results were reported in mouse experiments. $\mathrm{B}_{\mathrm{RM}}$, resident memory B-cells; DCs, dendritic cells; LPS, lipopolysaccharide; $S$. typhimurium, Salmonella typhimurium; $\mathrm{T}_{\mathrm{h} 1}$, type-1 helper T-cells; $\mathrm{T}_{\mathrm{h} 2}$, type-2 helper T-cells; $\mathrm{T}_{\mathrm{h} 17}$, T helper-17 cells; $\mathrm{T}_{\mathrm{RM}}$, resident memory T-cells. 
S. pneumoniae is the leading causative pathogen for CAP and, therefore, not only accounts for a high proportion of infectious mortality, but also confers serious long-term morbidity, i.e., a high incidence of cardiovascular events $[10,27,29]$. Three conventional vaccines are currently licensed against $S$. pneumoniae infection, which successfully reduced all-cause pneumonia and also invasive pneumococcal disease, although it remains to be shown whether all-cause mortality can be similarly reduced by these vaccines [21]. Consequently, and due to a need for broader serotype coverage and more effective long-term protection [139], efforts have been launched to test the potential of an (O)MV-based vaccine against S. pneumoniae infection. An initial study demonstrated the efficacy of native S. pneumoniae MVs applied intranasally in a mouse model, as displayed by robust IgG responses and markedly reduced mortality after infection [47]. The MVs used for these experiments were carrying well-known virulence proteins, including pneumolysin and pneumococcal surface protein A (PspA). These virulence factors were selected to induce a potent and broad immune response, as, e.g., pneumolysin is known to be present on virtually all $S$. pneumoniae serotypes $[140,141]$. However, it is questionable whether such vaccine formulations may be applied to humans due to considerable safety concerns, as native S. pneumoniae OMVs are able to induce harmful effects by interacting with humoral components of innate immunity, as described above $[55,70]$. Thus, a number of studies focused on OMVs from either S. typhimurium or E. coli, which were genetically modified in order to express pneumococcal proteins. Intranasal application of PspA-loaded S. typhimurium-derived OMVs reduced bacterial replication following subsequent $S$. pneumonia infection in vivo resulting in a considerable reduction in infection-attributed deaths $[126,127]$. Nevertheless, tolerability and safety concerns will also require careful assessment in this strategy, as some of the animals exhibited serious weight loss of more than $20 \%$ after vaccination [127]. With respect to safety concerns, the use of OMVs from a non-pathogenic E. coli strain (e.g., CLM37, which lacks $\mathrm{O}$ antigen and enterobacterial common antigen (ECA) synthesis [142]) may provide a promising approach. Intraperitoneally injected CLM37 E. coli-derived OMVs engineered to express a capsule glycan of $S$. pneumoniae serotype 14 were sufficient to induce the production of neutralizing antibodies [128]. Even though the surface molecule used in this study would not provide protection against other serotypes, it provides an encouraging proof-of-principle that glyco-engineered OMVs from non-pathogenic bacteria could present an efficient and safe vaccine strategy.

While of limited importance in community-acquired infections, $A$. baumannii has become a global threat as nosocomial pathogen accounting for both respirator-associated and systemic infections, with an emerging concern regarding multidrug-resistant strains [143]. Accordingly, development of an efficient vaccine is of great demand. Similar to vaccine development programs against B. pertussis and S. pneumoniae, native OMVs of the pathogen itself, OMVs from modified A. baumannii strains, and engineered OMVs from other bacteria have been tested as vaccine candidates. Native OMVs, applied mostly via the intramuscular, but also the intraperitoneal or the intranasal route, are able to induce a robust antibody response and prevent death following infection with A. baumannii, including multidrugresistant strains [129-133]. At the cellular level, OMVs not only activated B-cells, but also upregulated the costimulatory molecules CD80 and CD86 and MHC-II in DCs in vitro, and consequently induced a robust $\mathrm{T}_{\mathrm{h} 2}$ response in vivo [134]. Efforts to achieve better tolerability include testing of LPS-depleted OMVs, which yielded mixed results. OMVs secreted by an $A$. baumannii strain with reduced LPS endotoxicity protected from infection-associated mortality (including multidrug-resistant strains) when administrated together with an $A$. baumannii surface protein (biofilm-associated protein (Bap) ${ }_{(1-487 a a)}$ ) [135]. However, OMVs from an LPS-deficient strain (IB010) were inferior to OMVs from a wildtype strain (ATCC 19606), expressing higher levels of LPS [131]. Similar to strategies against S. pneumoniae discussed above, it seems promising to evaluate the immunogenic potential of OMVs from other non-pathogenic bacterial strains, which could be genetically modified to express $A$. baumannii antigens. Indeed, E. coli-derived OMVs genetically engineered to express the Acinetobacter surface protein Omp22 efficiently reduced systemic inflammatory responses 
and bacterial replication upon $A$. baumannii infection, and protected from a fatal course of the disease after subcutaneous injection [136]. Further studies will have to confirm whether this promising vaccine candidate can become a contender for clinical testing of new vaccination strategies against $A$. baumannii.

Quite similar to A. baumannii, K. pneumoniae is frequently the cause for antibioticresistant nosocomial infections, even though the pathogen is most prevalent in immunocompromised individuals [108]. The concept of OMV vaccination also seems to work for this pathogen as demonstrated by induction of a $\mathrm{T}_{\mathrm{h} 1}$ response and prevention of infectious death following intraperitoneal administration of native $K$. pneumoniae-secreted OMVs in a mouse model [137]. A novel approach evaluated whether binding of OMVs to albuminbased nanoparticles could enable an effective vaccination. A previous study already highlighted that a similar approach of coating gold nanoparticles with E. coli membranes allowed for efficient vaccination [144]. Indeed, the application of a nanoparticle-bound OMV vaccine was effective in preventing mice from infection with carbapenem-resistant $K$. pneumoniae after subcutaneous OMV application [138]. Intriguingly, this formulation led to even higher levels of antibodies and was more efficient in preventing fatal outcome as compared to native K. pneumoniae-derived OMVs, which was attributed to a potentially higher stability of the OMVs when bound to nanoparticles [138]. Taken together, (O)MVs from less pathogenic serotypes or surface-engineered (O)MVs from other, less pathogenic bacteria may pave the way for the development of not only effective but also safe (O)MVbased vaccines for airborne pathogens that continue to pose serious global threats at the current state.

\section{Conclusions}

A growing body of work is starting to highlight the role of $(\mathrm{O}) \mathrm{MVs}$ in bacterial infectious diseases of the lung. While $(\mathrm{O}) \mathrm{MVs}$ from various bacteria induce an inflammatory activation of both the pulmonary epithelium and innate immune cells, distinct virulence mechanisms exist for specific pathogens. Specifically, emerging evidence suggests that OMVs play an important role in the pathogenicity of P. aeruginosa in CF patients where they may aggravate bronchial epithelial hyposecretion in infectious exacerbations. Further effects with pathogenic potential include the induction of mitochondrial damage in both pulmonary epithelial cells and macrophages by A. baumannii OMVs, increased intracellular replication of L. pneumophila in macrophages following exposure to OMVs, inhibition of complement components and neutrophil extracellular traps by $S$. pneumoniae MVs, and induction of CD4 ${ }^{+}$T-cell anergy by M. tuberculosis MVs. At present, our insight into these effects is yet confined to a limited number of pathogen-host interactions, and a better in-depth understanding of the underlying molecular processes is required for the identification of specific targets for potential therapeutic approaches to treat pulmonary infections.

An important, yet so far rather unexplored aspect, which could additionally contribute to a better understanding of the development of bacterial infections and their virulence, is a more detailed exploration of the role of the commensal lung microbiome. While it is, for example, well known that the commensal microbiome plays a key role in maintaining gastrointestinal homeostasis not only by preventing infections but, e.g., also by protecting barrier integrity, information is limited with respect to its composition and physiological role in the lung $[145,146]$. Yet, an initial study on lung fibrosis in mice highlights not only the importance of the commensal pulmonary microbiome but also the pathogenic potential of its dysregulation and the mediating effects of related (O)MVs [147].

Notably, the effects of $(\mathrm{O}) \mathrm{MVs}$ on the respiratory tract are not confined to respiratory infections, as (O)MVs are also present in indoor dust in sufficient amounts to induce inflammatory responses in vivo $[148,149]$. Potential pathophysiological effects of (O)MVs should, therefore, not only be considered in the context of infection immunology but rather also in the growing field of human-environment interaction. 
Apart from their important role in bacterial pathogenicity, $(\mathrm{O}) \mathrm{MV}$ s have gained considerable interest as a novel vaccine platform. To date no clinical trials for $(\mathrm{O}) \mathrm{MV}$-based vaccines against pulmonary pathogens have been performed. Yet, a number of studies highlight the potential of (O)MV-based vaccine candidates against B. pertussis, S. pneumoniae, A. baumannii, and K. pneumoniae in vivo, which could, when successfully tested in the clinics, help overcome limited vaccine coverage for certain bacterial serotypes and reduce the marked morbidity induced by nosocomial infections. However, one has to consider that a rocky road might still lie ahead before such ambition may turn into reality, as major obstacles still remain to be overcome. On the one hand, pharmacological aspects like optimized formulation and administration route need to be addressed. On the other hand, it remains to be resolved how $(\mathrm{O}) \mathrm{MVs}$ may be utilized as safe vaccine candidates in spite of their ability to induce severe inflammatory phenotypes. First approaches, like the use of less pathogenic strains for the formulation of safer $(\mathrm{O}) \mathrm{MV}$-based vaccines, or surfaceengineered $(\mathrm{O}) \mathrm{MVs}$ from other, less pathogenic bacteria yield promising results, but remain to be translated into the clinical scenario. At present, $(\mathrm{O}) \mathrm{MVs}$ remain a double-edged sword with both pathophysiological impact and immunizing potentials.

Author Contributions: F.B., T.C.F.-H., W.M.K. and S.S. have substantially contributed to the conception or design of the work, designed the figure and tables, drafted the article, and revised it critically for important intellectual content. All authors have approved the final version of the article to be published, and agreed to be accountable for all aspects of the work in ensuring that questions related to the accuracy or integrity of any part of the work are appropriately investigated and resolved. All authors have read and agreed to the published version of the manuscript.

Funding: FB was supported by the Berlin Institute of Health (BIH). WMK was supported by the German Research Foundation (DFG), the Federal Ministry of Education and Research (BMBF), and the German Centre for Cardiovascular Research (DZHK). SS was supported by the German Foundation of Heart Research.

Acknowledgments: We acknowledge support from the German Research Federation (DFG) and the Open Access Publication Funds of Charité-Universitätsmedizin Berlin.

Conflicts of Interest: The authors declare they have no competing interests.

$\begin{array}{ll}\text { Abbreviations } \\ \text { CAP } & \begin{array}{l}\text { community-acquired pneumonia } \\ \text { Cystic fibrosis }\end{array} \\ \text { CFTR } & \begin{array}{l}\text { cystic fibrosis transductance regulator } \\ \text { Cif }\end{array} \\ \text { cystic fibrosis transductance regulator inhibitory factor } \\ \text { chronic obstructive pulmonary disease } \\ \text { DC } & \text { dendritic cell } \\ \text { DRP1 } & \text { dynamin-related protein 1 } \\ \text { EVs } & \text { extracellular vesicles } \\ \text { HAP } & \text { hospital-acquired pneumonia } \\ \text { IgD } & \text { immunoglobulin D } \\ \text { IL } & \text { interleukin } \\ \text { LPS } & \text { lipopolysaccharide } \\ \text { MHC } & \text { major histocompatibility complex } \\ \text { MID } & \text { moraxella IgD binding protein } \\ \text { MVs } & \text { membrane vesicles } \\ \text { NETs } & \text { neutrophil extracellular traps } \\ \text { Omp Ab } & \text { outer membrane protein A } \\ \text { (O)MVs } & \text { (outer) membrane vesicles } \\ \text { PspA } & \text { pneumococcal surface protein A } \\ \text { TLR } & \text { toll-like receptor } \\ \text { TNF- } \alpha & \text { tumor necrosis factor } \alpha \\ \text { USP10 } & \text { ubiquitin specific peptidase 10 }\end{array}$




\section{References}

1. GBD 2013 Mortality and Causes of Death Collaborators, Global, regional, and national age-sex specific all-cause and cause-specific mortality for 240 causes of death, 1990-2013: A systematic analysis for the Global Burden of Disease Study 2013. Lancet 2015, 385, 117-171. [CrossRef]

2. World Health Organization. The Top 10 Causes of Death. Available online: https://www.who.int/news-room/fact-sheets/ detail/the-top-10-causes-of-death (accessed on 16 February 2021).

3. Lanks, C.W.; Musani, A.I.; Hsia, D.W. Community-acquired Pneumonia and Hospital-acquired Pneumonia. Med. Clin. 2019, 103, 487-501. [CrossRef]

4. Magill, S.S.; O'Leary, E.; Janelle, S.J.; Thompson, D.L.; Dumyati, G.; Nadle, J.; Wilson, L.E.; Kainer, M.A.; Lynfield, R.; Greissman, S.; et al. Changes in Prevalence of Health Care-Associated Infections in U.S. Hospitals. N. Engl. J. Med. 2018, 379, 1732-1744. [CrossRef]

5. Musher, D.M.; Thorner, A.R. Community-acquired pneumonia. N. Engl. J. Med. 2014, 371, 1619-1628. [CrossRef] [PubMed]

6. Jones, R.N. Microbial etiologies of hospital-acquired bacterial pneumonia and ventilator-associated bacterial pneumonia. Clin. Infect. Dis. 2010, 51 (Suppl. 1), S81-S87. [CrossRef]

7. Welte, T.; Torres, A.; Nathwani, D. Clinical and economic burden of community-acquired pneumonia among adults in Europe. Thorax 2012, 67, 71-79. [CrossRef] [PubMed]

8. Costa, M.I.; Cipriano, A.; Santos, F.V.; Valdoleiros, S.R.; Furtado, I.; Machado, A.; Abreu, M.; Bastos, H.N. Clinical profile and microbiological aetiology diagnosis in adult patients hospitalized with community-acquired pneumonia. Pulmonology 2020. [CrossRef]

9. Jain, S.; Self, W.H.; Wunderink, R.G.; Fakhran, S.; Balk, R.; Bramley, A.M.; Reed, C.; Grijalva, C.G.; Anderson, E.J.; Courtney, D.M.; et al. Community-Acquired Pneumonia Requiring Hospitalization. N. Engl. J. Med. 2015, 373, 2382. [CrossRef]

10. Prina, E.; Ranzani, O.T.; Torres, A. Community-acquired pneumonia. Lancet 2015, 386, 1097-1108. [CrossRef]

11. Wedzicha, J.A.; Seemungal, T.A. COPD exacerbations: Defining their cause and prevention. Lancet 2007, 370, 786-796. [CrossRef]

12. Zemanick, E.T.; Hoffman, L.R. Cystic Fibrosis: Microbiology and Host Response. Pediatr. Clin. 2016, 63, 617-636. [CrossRef]

13. Baumann, U.; Routes, J.M.; Soler-Palacin, P.; Jolles, S. The Lung in Primary Immunodeficiencies: New Concepts in Infection and Inflammation. Front. Immunol. 2018, 9, 1837. [CrossRef] [PubMed]

14. Di Pasquale, M.F.; Sotgiu, G.; Gramegna, A.; Radovanovic, D.; Terraneo, S.; Reyes, L.F.; Rupp, J.; Gonzalez Del Castillo, J.; Blasi, F.; Aliberti, S.; et al. Prevalence and Etiology of Community-acquired Pneumonia in Immunocompromised Patients. Clin. Infect. Dis. 2019, 68, 1482-1493. [CrossRef] [PubMed]

15. Sapey, E.; Stockley, R.A. COPD exacerbations. 2: Aetiology. Thorax 2006, 61, 250-258. [CrossRef] [PubMed]

16. Elborn, J.S. Cystic fibrosis. Lancet 2016, 388, 2519-2531. [CrossRef]

17. Blanchard, A.C.; Waters, V.J. Microbiology of Cystic Fibrosis Airway Disease. Semin. Respir. Crit. Care Med. 2019, 40, 727-736. [CrossRef]

18. Monso, E.; Ruiz, J.; Rosell, A.; Manterola, J.; Fiz, J.; Morera, J.; Ausina, V. Bacterial infection in chronic obstructive pulmonary disease. A study of stable and exacerbated outpatients using the protected specimen brush. Am. J. Respir. Crit. Care Med. 1995 152, 1316-1320. [CrossRef]

19. Fagon, J.Y.; Chastre, J.; Trouillet, J.L.; Domart, Y.; Dombret, M.C.; Bornet, M.; Gibert, C. Characterization of distal bronchial microflora during acute exacerbation of chronic bronchitis. Use of the protected specimen brush technique in 54 mechanically ventilated patients. Am. Rev. Respir. Dis. 1990, 142, 1004-1008. [CrossRef]

20. Soler, N.; Torres, A.; Ewig, S.; Gonzalez, J.; Celis, R.; El-Ebiary, M.; Hernandez, C.; Rodriguez-Roisin, R. Bronchial microbial patterns in severe exacerbations of chronic obstructive pulmonary disease (COPD) requiring mechanical ventilation. Am. J. Respir. Crit. Care Med. 1998, 157, 1498-1505. [CrossRef] [PubMed]

21. Moberley, S.; Holden, J.; Tatham, D.P.; Andrews, R.M. Vaccines for preventing pneumococcal infection in adults. Cochrane Database Syst. Rev. 2013, 1. [CrossRef] [PubMed]

22. Roush, S.W.; Murphy, T.V.; Vaccine-Preventable Disease Table Working Group. Historical comparisons of morbidity and mortality for vaccine-preventable diseases in the United States. JAMA 2007, 298, 2155-2163. [CrossRef] [PubMed]

23. Buchy, P.; Badur, S. Who and when to vaccinate against influenza. Int. J. Infect. Dis. 2020, 93, 375-387. [CrossRef] [PubMed]

24. Ho, J.; Ip, M. Antibiotic-Resistant Community-Acquired Bacterial Pneumonia. Infect. Dis. Clin. 2019, 33, 1087-1103. [CrossRef] [PubMed]

25. Matthay, M.A.; Ware, L.B.; Zimmerman, G.A. The acute respiratory distress syndrome. J. Clin. Investig. 2012, 122, 2731-2740. [CrossRef] [PubMed]

26. Pereira, J.M.; Paiva, J.A.; Rello, J. Severe sepsis in community-acquired pneumonia-early recognition and treatment. Eur. J. Intern. Med. 2012, 23, 412-419. [CrossRef]

27. Corrales-Medina, V.F.; Alvarez, K.N.; Weissfeld, L.A.; Angus, D.C.; Chirinos, J.A.; Chang, C.C.; Newman, A.; Loehr, L.; Folsom, A.R.; Elkind, M.S.; et al. Association between hospitalization for pneumonia and subsequent risk of cardiovascular disease. JAMA 2015, 313, 264-274. [CrossRef]

28. Corrales-Medina, V.F.; Musher, D.M.; Shachkina, S.; Chirinos, J.A. Acute pneumonia and the cardiovascular system. Lancet 2013, 381, 496-505. [CrossRef] 
29. Bartlett, B.; Ludewick, H.P.; Lee, S.; Dwivedi, G. Cardiovascular complications following pneumonia: Focus on pneumococcus and heart failure. Curr. Opin. Cardiol. 2019, 34, 233-239. [CrossRef]

30. Kim, J.H.; Lee, J.; Park, J.; Gho, Y.S. Gram-negative and Gram-positive bacterial extracellular vesicles. Semin. Cell Dev. Biol. 2015, 40, 97-104. [CrossRef] [PubMed]

31. Maas, S.L.N.; Breakefield, X.O.; Weaver, A.M. Extracellular Vesicles: Unique Intercellular Delivery Vehicles. Trends Cell Biol. 2017, 27, 172-188. [CrossRef] [PubMed]

32. Deatherage, B.L.; Cookson, B.T. Membrane vesicle release in bacteria, eukaryotes, and archaea: A conserved yet underappreciated aspect of microbial life. Infect. Immun. 2012, 80, 1948-1957. [CrossRef]

33. Brown, L.; Wolf, J.M.; Prados-Rosales, R.; Casadevall, A. Through the wall: Extracellular vesicles in Gram-positive bacteria, mycobacteria and fungi. Nat. Rev. Microbiol. 2015, 13, 620-630. [CrossRef] [PubMed]

34. Toyofuku, M.; Nomura, N.; Eberl, L. Types and origins of bacterial membrane vesicles. Nat. Rev. Microbiol. 2019, 17, 13-24. [CrossRef] [PubMed]

35. Takaki, K.; Tahara, Y.O.; Nakamichi, N.; Hasegawa, Y.; Shintani, M.; Ohkuma, M.; Miyata, M.; Futamata, H.; Tashiro, Y. Multilamellar and Multivesicular Outer Membrane Vesicles Produced by a Buttiauxella agrestis tolB Mutant. Appl. Environ. Microbiol. 2020, 86. [CrossRef]

36. Takeo, K.; Uesaka, I.; Uehira, K.; Nishiura, M. Fine structure of Cryptococcus neoformans grown in vivo as observed by freeze-etching. J. Bacteriol. 1973, 113, 1449-1454. [CrossRef] [PubMed]

37. Schwechheimer, C.; Kuehn, M.J. Outer-membrane vesicles from Gram-negative bacteria: Biogenesis and functions. Nat. Rev. Microbiol. 2015, 13, 605-619. [CrossRef] [PubMed]

38. Work, E.; Knox, K.W.; Vesk, M. The chemistry and electron microscopy of an extracellular lipopolysaccharide from Escherichia coli. Ann. N. Y. Acad. Sci. 1966, 133, 438-449. [CrossRef]

39. Thery, C.; Witwer, K.W.; Aikawa, E.; Alcaraz, M.J.; Anderson, J.D.; Andriantsitohaina, R.; Antoniou, A.; Arab, T.; Archer, F.; Atkin-Smith, G.K.; et al. Minimal information for studies of extracellular vesicles 2018 (MISEV2018): A position statement of the International Society for Extracellular Vesicles and update of the MISEV2014 guidelines. J. Extracell. Vesicles 2018, 7, 1535750. [CrossRef] [PubMed]

40. Lane, R.E.; Korbie, D.; Trau, M.; Hill, M.M. Purification Protocols for Extracellular Vesicles. Methods Mol. Biol. 2017, 1660, 111-130. [CrossRef]

41. Cizmar, P.; Yuana, Y. Detection and Characterization of Extracellular Vesicles by Transmission and Cryo-Transmission Electron Microscopy. Methods Mol. Biol. 2017, 1660, 221-232. [CrossRef] [PubMed]

42. Szatanek, R.; Baj-Krzyworzeka, M.; Zimoch, J.; Lekka, M.; Siedlar, M.; Baran, J. The Methods of Choice for Extracellular Vesicles (EVs) Characterization. Int. J. Mol. Sci. 2017, 18, 1153. [CrossRef]

43. Nolan, J.P.; Duggan, E. Analysis of Individual Extracellular Vesicles by Flow Cytometry. Methods Mol. Biol. 2018, 1678, 79-92. [CrossRef] [PubMed]

44. Choi, D.S.; Kim, D.K.; Kim, Y.K.; Gho, Y.S. Proteomics of extracellular vesicles: Exosomes and ectosomes. Mass Spectrom. Rev. 2015, 34, 474-490. [CrossRef]

45. Everaert, C.; Helsmoortel, H.; Decock, A.; Hulstaert, E.; Van Paemel, R.; Verniers, K.; Nuytens, J.; Anckaert, J.; Nijs, N.; Tulkens, J.; et al. Performance assessment of total RNA sequencing of human biofluids and extracellular vesicles. Sci. Rep. 2019, 9, 17574. [CrossRef]

46. Kreimer, S.; Belov, A.M.; Ghiran, I.; Murthy, S.K.; Frank, D.A.; Ivanov, A.R. Mass-spectrometry-based molecular characterization of extracellular vesicles: Lipidomics and proteomics. J. Proteome Res. 2015, 14, 2367-2384. [CrossRef]

47. Olaya-Abril, A.; Prados-Rosales, R.; McConnell, M.J.; Martin-Pena, R.; Gonzalez-Reyes, J.A.; Jimenez-Munguia, I.; Gomez-Gascon, L.; Fernandez, J.; Luque-Garcia, J.L.; Garcia-Lidon, C.; et al. Characterization of protective extracellular membrane-derived vesicles produced by Streptococcus pneumoniae. J. Proteom. 2014, 106, 46-60. [CrossRef] [PubMed]

48. Koeppen, K.; Hampton, T.H.; Jarek, M.; Scharfe, M.; Gerber, S.A.; Mielcarz, D.W.; Demers, E.G.; Dolben, E.L.; Hammond, J.H.; Hogan, D.A.; et al. A Novel Mechanism of Host-Pathogen Interaction through sRNA in Bacterial Outer Membrane Vesicles. PLoS Pathog. 2016, 12, e1005672. [CrossRef]

49. Galka, F.; Wai, S.N.; Kusch, H.; Engelmann, S.; Hecker, M.; Schmeck, B.; Hippenstiel, S.; Uhlin, B.E.; Steinert, M. Proteomic characterization of the whole secretome of Legionella pneumophila and functional analysis of outer membrane vesicles. Infect. Immun. 2008, 76, 1825-1836. [CrossRef] [PubMed]

50. Athman, J.J.; Sande, O.J.; Groft, S.G.; Reba, S.M.; Nagy, N.; Wearsch, P.A.; Richardson, E.T.; Rojas, R.; Boom, W.H.; Shukla, S.; et al. Mycobacterium tuberculosis Membrane Vesicles Inhibit T Cell Activation. J. Immunol. 2017, 198, 2028-2037. [CrossRef] [PubMed]

51. Tiku, V.; Kofoed, E.M.; Yan, D.; Kang, J.; Xu, M.; Reichelt, M.; Dikic, I.; Tan, M.W. Outer membrane vesicles containing OmpA induce mitochondrial fragmentation to promote pathogenesis of Acinetobacter baumannii. Sci. Rep. 2021, 11, 618. [CrossRef]

52. Schaar, V.; Nordstrom, T.; Morgelin, M.; Riesbeck, K. Moraxella catarrhalis outer membrane vesicles carry beta-lactamase and promote survival of Streptococcus pneumoniae and Haemophilus influenzae by inactivating amoxicillin. Antimicrob. Agents Chemother. 2011, 55, 3845-3853. [CrossRef]

53. MacEachran, D.P.; Ye, S.; Bomberger, J.M.; Hogan, D.A.; Swiatecka-Urban, A.; Stanton, B.A.; O’Toole, G.A. The Pseudomonas aeruginosa secreted protein PA2934 decreases apical membrane expression of the cystic fibrosis transmembrane conductance regulator. Infect. Immun. 2007, 75, 3902-3912. [CrossRef] 
54. Nho, J.S.; Jun, S.H.; Oh, M.H.; Park, T.I.; Choi, C.W.; Kim, S.I.; Choi, C.H.; Lee, J.C. Acinetobacter nosocomialis secretes outer membrane vesicles that induce epithelial cell death and host inflammatory responses. Microb. Pathog. 2015, 81, 39-45. [CrossRef] [PubMed]

55. Jhelum, H.; Sori, H.; Sehgal, D. A novel extracellular vesicle-associated endodeoxyribonuclease helps Streptococcus pneumoniae evade neutrophil extracellular traps and is required for full virulence. Sci. Rep. 2018, 8, 7985. [CrossRef]

56. Bauman, S.J.; Kuehn, M.J. Purification of outer membrane vesicles from Pseudomonas aeruginosa and their activation of an IL-8 response. Microbes Infect. 2006, 8, 2400-2408. [CrossRef]

57. Bauman, S.J.; Kuehn, M.J. Pseudomonas aeruginosa vesicles associate with and are internalized by human lung epithelial cells. BMC Microbiol. 2009, 9, 26. [CrossRef]

58. Yun, S.H.; Park, E.C.; Lee, S.Y.; Lee, H.; Choi, C.W.; Yi, Y.S.; Ro, H.J.; Lee, J.C.; Jun, S.; Kim, H.Y.; et al. Antibiotic treatment modulates protein components of cytotoxic outer membrane vesicles of multidrug-resistant clinical strain, Acinetobacter baumannii DU202. Clin. Proteom. 2018, 15, 28. [CrossRef]

59. Nguyen, L.; Pieters, J. The Trojan horse: Survival tactics of pathogenic mycobacteria in macrophages. Trends Cell Biol. 2005, 15, 269-276. [CrossRef]

60. Ehrt, S.; Schnappinger, D.; Rhee, K.Y. Metabolic principles of persistence and pathogenicity in Mycobacterium tuberculosis. Nat. Rev. Microbiol. 2018, 16, 496-507. [CrossRef] [PubMed]

61. Qiu, J.; Luo, Z.Q. Legionella and Coxiella effectors: Strength in diversity and activity. Nat. Rev. Microbiol. 2017, 15, 591-605 [CrossRef]

62. Bhatnagar, S.; Schorey, J.S. Exosomes released from infected macrophages contain Mycobacterium avium glycopeptidolipids and are proinflammatory. J. Biol. Chem. 2007, 282, 25779-25789. [CrossRef]

63. Bhatnagar, S.; Shinagawa, K.; Castellino, F.J.; Schorey, J.S. Exosomes released from macrophages infected with intracellular pathogens stimulate a proinflammatory response in vitro and in vivo. Blood 2007, 110, 3234-3244. [CrossRef] [PubMed]

64. Ramachandra, L.; Qu, Y.; Wang, Y.; Lewis, C.J.; Cobb, B.A.; Takatsu, K.; Boom, W.H.; Dubyak, G.R.; Harding, C.V. Mycobacterium tuberculosis synergizes with ATP to induce release of microvesicles and exosomes containing major histocompatibility complex class II molecules capable of antigen presentation. Infect. Immun. 2010, 78, 5116-5125. [CrossRef]

65. Giri, P.K.; Schorey, J.S. Exosomes derived from M. Bovis BCG infected macrophages activate antigen-specific CD4+ and CD8+ T cells in vitro and in vivo. PLoS ONE 2008, 3, e2461. [CrossRef] [PubMed]

66. Singh, P.P.; Smith, V.L.; Karakousis, P.C.; Schorey, J.S. Exosomes isolated from mycobacteria-infected mice or cultured macrophages can recruit and activate immune cells in vitro and in vivo. J. Immunol. 2012, 189, 777-785. [CrossRef] [PubMed]

67. Singh, P.P.; LeMaire, C.; Tan, J.C.; Zeng, E.; Schorey, J.S. Exosomes released from M. tuberculosis infected cells can suppress IFN-gamma mediated activation of naive macrophages. PLoS ONE 2011, 6, e18564. [CrossRef]

68. Athman, J.J.; Wang, Y.; McDonald, D.J.; Boom, W.H.; Harding, C.V.; Wearsch, P.A. Bacterial Membrane Vesicles Mediate the Release of Mycobacterium tuberculosis Lipoglycans and Lipoproteins from Infected Macrophages. J. Immunol. 2015, 195, 1044-1053. [CrossRef]

69. Barnaby, R.; Koeppen, K.; Stanton, B.A. Cyclodextrins reduce the ability of Pseudomonas aeruginosa outer-membrane vesicles to reduce CFTR Cl(-) secretion. Am. J. Physiol. Lung Cell. Mol. Physiol. 2019, 316, L206-L215. [CrossRef]

70. Codemo, M.; Muschiol, S.; Iovino, F.; Nannapaneni, P.; Plant, L.; Wai, S.N.; Henriques-Normark, B. Immunomodulatory Effects of Pneumococcal Extracellular Vesicles on Cellular and Humoral Host Defenses. mBio 2018, 9. [CrossRef]

71. Arasu, U.T.; Deen, A.J.; Pasonen-Seppanen, S.; Heikkinen, S.; Lalowski, M.; Karna, R.; Harkonen, K.; Makinen, P.; Lazaro-Ibanez E.; Siljander, P.R.; et al. HAS3-induced extracellular vesicles from melanoma cells stimulate IHH mediated c-Myc upregulation via the hedgehog signaling pathway in target cells. Cell. Mol. Life Sci. 2020, 77, 4093-4115. [CrossRef]

72. Ragni, E.; Perucca Orfei, C.; De Luca, P.; Lugano, G.; Vigano, M.; Colombini, A.; Valli, F.; Zacchetti, D.; Bollati, V.; de Girolamo, L. Interaction with hyaluronan matrix and miRNA cargo as contributors for in vitro potential of mesenchymal stem cell-derived extracellular vesicles in a model of human osteoarthritic synoviocytes. Stem Cell Res. Ther. 2019, 10, 109. [CrossRef]

73. Morath, I.; Hartmann, T.N.; Orian-Rousseau, V. CD44: More than a mere stem cell marker. Int. J. Biochem. Cell Biol. 2016, 81, 166-173. [CrossRef]

74. Ochs, M.; Hegermann, J.; Lopez-Rodriguez, E.; Timm, S.; Nouailles, G.; Matuszak, J.; Simmons, S.; Witzenrath, M.; Kuebler, W.M. On Top of the Alveolar Epithelium: Surfactant and the Glycocalyx. Int. J. Mol. Sci. 2020, 21, 3075. [CrossRef] [PubMed]

75. Bomberger, J.M.; Maceachran, D.P.; Coutermarsh, B.A.; Ye, S.; O’Toole, G.A.; Stanton, B.A. Long-distance delivery of bacterial virulence factors by Pseudomonas aeruginosa outer membrane vesicles. PLoS Pathog. 2009, 5, e1000382. [CrossRef]

76. Mehanny, M.; Koch, M.; Lehr, C.M.; Fuhrmann, G. Streptococcal Extracellular Membrane Vesicles Are Rapidly Internalized by Immune Cells and Alter Their Cytokine Release. Front. Immunol. 2020, 11, 80. [CrossRef] [PubMed]

77. Stentz, R.; Carvalho, A.L.; Jones, E.J.; Carding, S.R. Fantastic voyage: The journey of intestinal microbiota-derived microvesicles through the body. Biochem. Soc. Trans. 2018, 46, 1021-1027. [CrossRef] [PubMed]

78. Rubio, A.P.D.; Martinez, J.; Palavecino, M.; Fuentes, F.; Lopez, C.M.S.; Marcilla, A.; Perez, O.E.; Piuri, M. Transcytosis of Bacillus subtilis extracellular vesicles through an in vitro intestinal epithelial cell model. Sci. Rep. 2020, 10, 3120. [CrossRef] [PubMed]

79. Li, Z.T.; Zhang, R.L.; Bi, X.G.; Xu, L.; Fan, M.; Xie, D.; Xian, Y.; Wang, Y.; Li, X.J.; Wu, Z.D.; et al. Outer membrane vesicles isolated from two clinical Acinetobacter baumannii strains exhibit different toxicity and proteome characteristics. Microb. Pathog. 2015, 81, 46-52. [CrossRef] [PubMed] 
80. Lee, J.C.; Lee, E.J.; Lee, J.H.; Jun, S.H.; Choi, C.W.; Kim, S.I.; Kang, S.S.; Hyun, S. Klebsiella pneumoniae secretes outer membrane vesicles that induce the innate immune response. FEMS Microbiol. Lett. 2012, 331, 17-24. [CrossRef] [PubMed]

81. Schaar, V.; de Vries, S.P.; Perez Vidakovics, M.L.; Bootsma, H.J.; Larsson, L.; Hermans, P.W.; Bjartell, A.; Morgelin, M.; Riesbeck, K. Multicomponent Moraxella catarrhalis outer membrane vesicles induce an inflammatory response and are internalized by human epithelial cells. Cell. Microbiol. 2011, 13, 432-449. [CrossRef]

82. Kim, Y.J.; Jeon, H.; Na, S.H.; Kwon, H.I.; Selasi, G.N.; Nicholas, A.; Park, T.I.; Lee, S.H.; Lee, J.C. Stenotrophomonas maltophilia outer membrane vesicles elicit a potent inflammatory response in vitro and in vivo. Pathog. Dis. 2016, 74. [CrossRef]

83. Park, K.S.; Lee, J.; Jang, S.C.; Kim, S.R.; Jang, M.H.; Lotvall, J.; Kim, Y.K.; Gho, Y.S. Pulmonary inflammation induced by bacteria-free outer membrane vesicles from Pseudomonas aeruginosa. Am. J. Respir. Cell Mol. Biol. 2013, 49, 637-645. [CrossRef] [PubMed]

84. Jager, J.; Marwitz, S.; Tiefenau, J.; Rasch, J.; Shevchuk, O.; Kugler, C.; Goldmann, T.; Steinert, M. Human lung tissue explants reveal novel interactions during Legionella pneumophila infections. Infect. Immun. 2014, 82, 275-285. [CrossRef] [PubMed]

85. Zegarra-Moran, O.; Galietta, L.J. CFTR pharmacology. Cell. Mol. Life Sci. 2017, 74, 117-128. [CrossRef]

86. Lund-Palau, H.; Turnbull, A.R.; Bush, A.; Bardin, E.; Cameron, L.; Soren, O.; Wierre-Gore, N.; Alton, E.W.; Bundy, J.G.; Connett, G.; et al. Pseudomonas aeruginosa infection in cystic fibrosis: Pathophysiological mechanisms and therapeutic approaches. Expert Rev. Respir. Med. 2016, 10, 685-697. [CrossRef] [PubMed]

87. Bomberger, J.M.; Ye, S.; Maceachran, D.P.; Koeppen, K.; Barnaby, R.L.; O’Toole, G.A.; Stanton, B.A. A Pseudomonas aeruginosa toxin that hijacks the host ubiquitin proteolytic system. PLoS Pathog. 2011, 7, e1001325. [CrossRef]

88. Grimmer, B.; Kuebler, W.M. The endothelium in hypoxic pulmonary vasoconstriction. J. Appl. Physiol. 2017, 123, 1635-1646. [CrossRef] [PubMed]

89. Bomberger, J.M.; Ely, K.H.; Bangia, N.; Ye, S.; Green, K.A.; Green, W.R.; Enelow, R.I.; Stanton, B.A. Pseudomonas aeruginosa Cif protein enhances the ubiquitination and proteasomal degradation of the transporter associated with antigen processing (TAP) and reduces major histocompatibility complex (MHC) class I antigen presentation. J. Biol. Chem. 2014, 289, 152-162. [CrossRef] [PubMed]

90. Jager, J.; Keese, S.; Roessle, M.; Steinert, M.; Schromm, A.B. Fusion of Legionella pneumophila outer membrane vesicles with eukaryotic membrane systems is a mechanism to deliver pathogen factors to host cell membranes. Cell. Microbiol. 2015, 17, 607-620. [CrossRef] [PubMed]

91. Deo, P.; Chow, S.H.; Han, M.L.; Speir, M.; Huang, C.; Schittenhelm, R.B.; Dhital, S.; Emery, J.; Li, J.; Kile, B.T.; et al. Mitochondrial dysfunction caused by outer membrane vesicles from Gram-negative bacteria activates intrinsic apoptosis and inflammation. Nat. Microbiol. 2020, 5, 1418-1427. [CrossRef]

92. Bitto, N.J.; Baker, P.J.; Dowling, J.K.; Wray-McCann, G.; De Paoli, A.; Tran, L.S.; Leung, P.L.; Stacey, K.J.; Mansell, A.; Masters, S.L.; et al. Membrane vesicles from Pseudomonas aeruginosa activate the noncanonical inflammasome through caspase-5 in human monocytes. Immunol. Cell Biol. 2018, 96, 1120-1130. [CrossRef]

93. Ellis, T.N.; Leiman, S.A.; Kuehn, M.J. Naturally produced outer membrane vesicles from Pseudomonas aeruginosa elicit a potent innate immune response via combined sensing of both lipopolysaccharide and protein components. Infect. Immun. 2010, 78, 3822-3831. [CrossRef]

94. Volgers, C.; Benedikter, B.J.; Grauls, G.E.; Savelkoul, P.H.M.; Stassen, F.R.M. Immunomodulatory role for membrane vesicles released by THP-1 macrophages and respiratory pathogens during macrophage infection. BMC Microbiol. 2017, 17, 216. [CrossRef] [PubMed]

95. Marion, C.R.; Lee, J.; Sharma, L.; Park, K.S.; Lee, C.; Liu, W.; Liu, P.; Feng, J.; Gho, Y.S.; Dela Cruz, C.S. Toll-Like Receptors 2 and 4 Modulate Pulmonary Inflammation and Host Factors Mediated by Outer Membrane Vesicles Derived from Acinetobacter baumannii. Infect. Immun. 2019, 87. [CrossRef] [PubMed]

96. Jung, A.L.; Herkt, C.E.; Schulz, C.; Bolte, K.; Seidel, K.; Scheller, N.; Sittka-Stark, A.; Bertrams, W.; Schmeck, B. Legionella pneumophila infection activates bystander cells differentially by bacterial and host cell vesicles. Sci. Rep. 2017, 7, 6301. [CrossRef] [PubMed]

97. Jung, A.L.; Stoiber, C.; Herkt, C.E.; Schulz, C.; Bertrams, W.; Schmeck, B. Legionella pneumophila-Derived Outer Membrane Vesicles Promote Bacterial Replication in Macrophages. PLoS Pathog. 2016, 12, e1005592. [CrossRef] [PubMed]

98. Fernandez-Moreira, E.; Helbig, J.H.; Swanson, M.S. Membrane vesicles shed by Legionella pneumophila inhibit fusion of phagosomes with lysosomes. Infect. Immun. 2006, 74, 3285-3295. [CrossRef]

99. Papayannopoulos, V. Neutrophil extracellular traps in immunity and disease. Nat. Rev. Immunol. 2018, 18, 134-147. [CrossRef] [PubMed]

100. Conigliaro, P.; Triggianese, P.; Ballanti, E.; Perricone, C.; Perricone, R.; Chimenti, M.S. Complement, infection, and autoimmunity. Curr. Opin. Rheumatol. 2019, 31, 532-541. [CrossRef]

101. Merle, N.S.; Noe, R.; Halbwachs-Mecarelli, L.; Fremeaux-Bacchi, V.; Roumenina, L.T. Complement System Part II: Role in Immunity. Front. Immunol. 2015, 6, 257. [CrossRef]

102. Parente, R.; Clark, S.J.; Inforzato, A.; Day, A.J. Complement factor H in host defense and immune evasion. Cell. Mol. Life Sci. 2017, 74, 1605-1624. [CrossRef] [PubMed]

103. Murphy, T.F.; Parameswaran, G.I. Moraxella catarrhalis, a human respiratory tract pathogen. Clin. Infect. Dis. 2009, 49, 124-131. [CrossRef] [PubMed] 
104. Vidakovics, M.L.; Jendholm, J.; Morgelin, M.; Mansson, A.; Larsson, C.; Cardell, L.O.; Riesbeck, K. B cell activation by outer membrane vesicles-A novel virulence mechanism. PLoS Pathog. 2010, 6, e1000724. [CrossRef] [PubMed]

105. Rosser, E.C.; Mauri, C. Regulatory B cells: Origin, phenotype, and function. Immunity 2015, 42, 607-612. [CrossRef] [PubMed]

106. Hasan, M.M.; Thompson-Snipes, L.; Klintmalm, G.; Demetris, A.J.; O'Leary, J.; Oh, S.; Joo, H. CD24(hi)CD38(hi) and CD24(hi)CD27(+) Human Regulatory B Cells Display Common and Distinct Functional Characteristics. J. Immunol. 2019, 203, 2110-2120. [CrossRef] [PubMed]

107. Antunes, L.C.; Visca, P.; Towner, K.J. Acinetobacter baumannii: Evolution of a global pathogen. Pathog. Dis. 2014, 71, $292-301$. [CrossRef] [PubMed]

108. Wyres, K.L.; Lam, M.M.C.; Holt, K.E. Population genomics of Klebsiella pneumoniae. Nat. Rev. Microbiol. 2020, 18, 344-359. [CrossRef] [PubMed]

109. File, T.M., Jr. Streptococcus pneumoniae and community-acquired pneumonia: A cause for concern. Am. J. Med. 2004, 117 (Suppl. 3A), 39S-50S. [CrossRef]

110. Kilgore, P.E.; Salim, A.M.; Zervos, M.J.; Schmitt, H.J. Pertussis: Microbiology, Disease, Treatment, and Prevention. Clin. Microbiol. Rev. 2016, 29, 449-486. [CrossRef]

111. Arigita, C.; Jiskoot, W.; Westdijk, J.; van Ingen, C.; Hennink, W.E.; Crommelin, D.J.; Kersten, G.F. Stability of mono- and trivalent meningococcal outer membrane vesicle vaccines. Vaccine 2004, 22, 629-642. [CrossRef] [PubMed]

112. Jang, S.C.; Kim, S.R.; Yoon, Y.J.; Park, K.S.; Kim, J.H.; Lee, J.; Kim, O.Y.; Choi, E.J.; Kim, D.K.; Choi, D.S.; et al. In vivo kinetic biodistribution of nano-sized outer membrane vesicles derived from bacteria. Small 2015, 11, 456-461. [CrossRef]

113. Holst, J.; Martin, D.; Arnold, R.; Huergo, C.C.; Oster, P.; O’Hallahan, J.; Rosenqvist, E. Properties and clinical performance of vaccines containing outer membrane vesicles from Neisseria meningitidis. Vaccine 2009, 27 (Suppl. 2), B3-B12. [CrossRef]

114. Barkoff, A.M.; He, Q. Molecular Epidemiology of Bordetella pertussis. Adv. Exp. Med. Biol. 2019, 1183, 19-33. [CrossRef]

115. Raeven, R.H.M.; Rockx-Brouwer, D.; Kanojia, G.; van der Maas, L.; Bindels, T.H.E.; Ten Have, R.; van Riet, E.; Metz, B.; Kersten, G.F.A. Intranasal immunization with outer membrane vesicle pertussis vaccine confers broad protection through mucosal IgA and Th17 responses. Sci. Rep. 2020, 10, 7396. [CrossRef] [PubMed]

116. Raeven, R.H.M.; Brummelman, J.; Pennings, J.L.A.; van der Maas, L.; Helm, K.; Tilstra, W.; van der Ark, A.; Sloots, A.; van der Ley, P.; van Eden, W.; et al. Molecular and cellular signatures underlying superior immunity against Bordetella pertussis upon pulmonary vaccination. Mucosal Immunol. 2018, 11, 1009. [CrossRef]

117. Roberts, R.; Moreno, G.; Bottero, D.; Gaillard, M.E.; Fingermann, M.; Graieb, A.; Rumbo, M.; Hozbor, D. Outer membrane vesicles as acellular vaccine against pertussis. Vaccine 2008, 26, 4639-4646. [CrossRef]

118. Raeven, R.H.; Brummelman, J.; Pennings, J.L.; van der Maas, L.; Tilstra, W.; Helm, K.; van Riet, E.; Jiskoot, W.; van Els, C.A.; Han, W.G.; et al. Bordetella pertussis outer membrane vesicle vaccine confers equal efficacy in mice with milder inflammatory responses compared to a whole-cell vaccine. Sci. Rep. 2016, 6, 38240. [CrossRef] [PubMed]

119. Zurita, M.E.; Wilk, M.M.; Carriquiriborde, F.; Bartel, E.; Moreno, G.; Misiak, A.; Mills, K.H.G.; Hozbor, D. A Pertussis Outer Membrane Vesicle-Based Vaccine Induces Lung-Resident Memory CD4 T Cells and Protection Against Bordetella pertussis, Including Pertactin Deficient Strains. Front. Cell. Infect. Microbiol. 2019, 9, 125. [CrossRef]

120. Gaillard, M.E.; Bottero, D.; Errea, A.; Ormazabal, M.; Zurita, M.E.; Moreno, G.; Rumbo, M.; Castuma, C.; Bartel, E.; Flores, D.; et al. Acellular pertussis vaccine based on outer membrane vesicles capable of conferring both long-lasting immunity and protection against different strain genotypes. Vaccine 2014, 32, 931-937. [CrossRef] [PubMed]

121. Bottero, D.; Gaillard, M.E.; Zurita, E.; Moreno, G.; Martinez, D.S.; Bartel, E.; Bravo, S.; Carriquiriborde, F.; Errea, A.; Castuma, C.; et al. Characterization of the immune response induced by pertussis OMVs-based vaccine. Vaccine 2016, 34, 3303-3309. [CrossRef]

122. Raeven, R.H.; van der Maas, L.; Tilstra, W.; Uittenbogaard, J.P.; Bindels, T.H.; Kuipers, B.; van der Ark, A.; Pennings, J.L.; van Riet, E.; Jiskoot, W.; et al. Immunoproteomic Profiling of Bordetella pertussis Outer Membrane Vesicle Vaccine Reveals Broad and Balanced Humoral Immunogenicity. J. Proteome Res. 2015, 14, 2929-2942. [CrossRef]

123. Raeven, R.H.M.; van Vlies, N.; Salverda, M.L.M.; van der Maas, L.; Uittenbogaard, J.P.; Bindels, T.H.E.; Rigters, J.; Verhagen, L.M.; Kruijer, S.; van Riet, E.; et al. The Role of Virulence Proteins in Protection Conferred by Bordetella pertussis Outer Membrane Vesicle Vaccines. Vaccines 2020, 8, 429. [CrossRef]

124. Ormazabal, M.; Bartel, E.; Gaillard, M.E.; Bottero, D.; Errea, A.; Zurita, M.E.; Moreno, G.; Rumbo, M.; Castuma, C.; Flores, D.; et al. Characterization of the key antigenic components of pertussis vaccine based on outer membrane vesicles. Vaccine 2014, 32, 6084-6090. [CrossRef]

125. Asensio, C.J.; Gaillard, M.E.; Moreno, G.; Bottero, D.; Zurita, E.; Rumbo, M.; van der Ley, P.; van der Ark, A.; Hozbor, D. Outer membrane vesicles obtained from Bordetella pertussis Tohama expressing the lipid A deacylase PagL as a novel acellular vaccine candidate. Vaccine 2011, 29, 1649-1656. [CrossRef]

126. Muralinath, M.; Kuehn, M.J.; Roland, K.L.; Curtiss, R., 3rd. Immunization with Salmonella enterica serovar Typhimurium-derived outer membrane vesicles delivering the pneumococcal protein PspA confers protection against challenge with Streptococcus pneumoniae. Infect. Immun. 2011, 79, 887-894. [CrossRef]

127. Kuipers, K.; Daleke-Schermerhorn, M.H.; Jong, W.S.; ten Hagen-Jongman, C.M.; van Opzeeland, F.; Simonetti, E.; Luirink, J.; de Jonge, M.I. Salmonella outer membrane vesicles displaying high densities of pneumococcal antigen at the surface offer protection against colonization. Vaccine 2015, 33, 2022-2029. [CrossRef] 
128. Price, N.L.; Goyette-Desjardins, G.; Nothaft, H.; Valguarnera, E.; Szymanski, C.M.; Segura, M.; Feldman, M.F. Glycoengineered Outer Membrane Vesicles: A Novel Platform for Bacterial Vaccines. Sci. Rep. 2016, 6, 24931. [CrossRef]

129. Huang, W.; Zhang, Q.; Li, W.; Chen, Y.; Shu, C.; Li, Q.; Zhou, J.; Ye, C.; Bai, H.; Sun, W.; et al. Anti-outer Membrane Vesicle Antibodies Increase Antibiotic Sensitivity of Pan-Drug-Resistant Acinetobacter baumannii. Front. Microbiol. $2019,10,1379$. [CrossRef]

130. Li, S.; Chen, D.Q.; Ji, L.; Sun, S.; Jin, Z.; Jin, Z.L.; Sun, H.W.; Zeng, H.; Zhang, W.J.; Lu, D.S.; et al. Development of Different Methods for Preparing Acinetobacter baumannii Outer Membrane Vesicles Vaccine: Impact of Preparation Method on Protective Efficacy. Front. Immunol. 2020, 11, 1069. [CrossRef]

131. Pulido, M.R.; Garcia-Quintanilla, M.; Pachon, J.; McConnell, M.J. A lipopolysaccharide-free outer membrane vesicle vaccine protects against Acinetobacter baumannii infection. Vaccine 2020, 38, 719-724. [CrossRef]

132. Huang, W.; Yao, Y.; Long, Q.; Yang, X.; Sun, W.; Liu, C.; Jin, X.; Li, Y.; Chu, X.; Chen, B.; et al. Immunization against multidrugresistant Acinetobacter baumannii effectively protects mice in both pneumonia and sepsis models. PLoS ONE 2014, 9, e100727. [CrossRef]

133. McConnell, M.J.; Rumbo, C.; Bou, G.; Pachon, J. Outer membrane vesicles as an acellular vaccine against Acinetobacter baumannii. Vaccine 2011, 29, 5705-5710. [CrossRef]

134. Cai, W.; Kesavan, D.K.; Cheng, J.; Vasudevan, A.; Wang, H.; Wan, J.; Abdelaziz, M.H.; Su, Z.; Wang, S.; Xu, H. Vesicle-Mediated Dendritic Cell Activation in Acinetobacter baumannii Clinical Isolate, which Contributes to Th2 Response. J. Immunol. Res. 2019, 2019, 2835256. [CrossRef]

135. Badmasti, F.; Ajdary, S.; Bouzari, S.; Fooladi, A.A.; Shahcheraghi, F.; Siadat, S.D. Immunological evaluation of OMV(PagL)+Bap(1487aa) and $\mathrm{AbOmpA}(8-346 \mathrm{aa})+\mathrm{Bap}(1-487 \mathrm{aa})$ as vaccine candidates against Acinetobacter baumannii sepsis infection. Mol. Immunol. 2015, 67, 552-558. [CrossRef]

136. Huang, W.; Wang, S.; Yao, Y.; Xia, Y.; Yang, X.; Li, K.; Sun, P.; Liu, C.; Sun, W.; Bai, H.; et al. Employing Escherichia coli-derived outer membrane vesicles as an antigen delivery platform elicits protective immunity against Acinetobacter baumannii infection. Sci. Rep. 2016, 6, 37242. [CrossRef]

137. Lee, W.H.; Choi, H.I.; Hong, S.W.; Kim, K.S.; Gho, Y.S.; Jeon, S.G. Vaccination with Klebsiella pneumoniae-derived extracellular vesicles protects against bacteria-induced lethality via both humoral and cellular immunity. Exp. Mol. Med. 2015, 47, e183. [CrossRef]

138. Wu, G.; Ji, H.; Guo, X.; Li, Y.; Ren, T.; Dong, H.; Liu, J.; Liu, Y.; Shi, X.; He, B. Nanoparticle reinforced bacterial outer-membrane vesicles effectively prevent fatal infection of carbapenem-resistant Klebsiella pneumoniae. Nanomedicine 2020, 24,102148 [CrossRef] [PubMed]

139. Berical, A.C.; Harris, D.; Dela Cruz, C.S.; Possick, J.D. Pneumococcal Vaccination Strategies. An Update and Perspective. Ann. Am. Thorac. Soc. 2016, 13, 933-944. [CrossRef]

140. Cockeran, R.; Anderson, R.; Feldman, C. The role of pneumolysin in the pathogenesis of Streptococcus pneumoniae infection. Curr. Opin. Infect. Dis. 2002, 15, 235-239. [CrossRef]

141. Mitchell, T.J.; Dalziel, C.E. The biology of pneumolysin. Subcell. Biochem. 2014, 80, 145-160. [CrossRef]

142. Linton, D.; Dorrell, N.; Hitchen, P.G.; Amber, S.; Karlyshev, A.V.; Morris, H.R.; Dell, A.; Valvano, M.A.; Aebi, M.; Wren, B.W. Functional analysis of the Campylobacter jejuni N-linked protein glycosylation pathway. Mol. Microbiol. 2005, 55, 1695-1703. [CrossRef]

143. Harding, C.M.; Hennon, S.W.; Feldman, M.F. Uncovering the mechanisms of Acinetobacter baumannii virulence. Nat. Rev. Microbiol. 2018, 16, 91-102. [CrossRef]

144. Gao, W.; Fang, R.H.; Thamphiwatana, S.; Luk, B.T.; Li, J.; Angsantikul, P.; Zhang, Q.; Hu, C.M.; Zhang, L. Modulating antibacterial immunity via bacterial membrane-coated nanoparticles. Nano Lett. 2015, 15, 1403-1409. [CrossRef]

145. Bartolomaeus, H.; Marko, L.; Wilck, N.; Luft, F.C.; Forslund, S.K.; Muller, D.N. Precarious Symbiosis Between Host and Microbiome in Cardiovascular Health. Hypertension 2019, 73, 926-935. [CrossRef]

146. Moffatt, M.F.; Cookson, W.O. The lung microbiome in health and disease. Clin. Med. 2017, 17, 525-529. [CrossRef] [PubMed]

147. Yang, D.; Chen, X.; Wang, J.; Lou, Q.; Lou, Y.; Li, L.; Wang, H.; Chen, J.; Wu, M.; Song, X.; et al. Dysregulated Lung Commensal Bacteria Drive Interleukin-17B Production to Promote Pulmonary Fibrosis through Their Outer Membrane Vesicles. Immunity 2019, 50, 692-706.e697. [CrossRef]

148. Kim, Y.S.; Choi, E.J.; Lee, W.H.; Choi, S.J.; Roh, T.Y.; Park, J.; Jee, Y.K.; Zhu, Z.; Koh, Y.Y.; Gho, Y.S.; et al. Extracellular vesicles, especially derived from Gram-negative bacteria, in indoor dust induce neutrophilic pulmonary inflammation associated with both Th1 and Th17 cell responses. Clin. Exp. Allergy 2013, 43, 443-454. [CrossRef]

149. Meganathan, V.; Moyana, R.; Natarajan, K.; Kujur, W.; Kusampudi, S.; Mulik, S.; Boggaram, V. Bacterial extracellular vesicles isolated from organic dust induce neutrophilic inflammation in the lung. Am. J. Physiol. Lung Cell. Mol. Physiol. 2020, 319, L893-L907. [CrossRef] 